\title{
River bacterioplankton community responses to a high inflow event
}

\author{
R. L. Carney ${ }^{1, *}$, S. M. Mitrovic ${ }^{2,3}$, T. Jeffries ${ }^{1}$, D. Westhorpe $^{3}$, N. Curlevski ${ }^{1}$, \\ J. R. Seymour ${ }^{1}$
}

${ }^{1}$ Plant Functional Biology and Climate Change Cluster (C3), University of Technology, Sydney, PO Box 123, Broadway, New South Wales 2007, Australia

${ }^{2}$ Centre for Environmental Sustainability (CENS), University of Technology, Sydney, PO Box 123, Broadway, New South Wales 2007, Australia

${ }^{3}$ Department of Primary Industries, Office of Water, PO Box 3720, Sydney, New South Wales 2024, Australia

\begin{abstract}
Microbes drive chemical cycling and productivity within river ecosystems, but their influence may shift when intense allochthonous inputs accompany high freshwater inflow (flood) events. Investigating how floods influence microbial processes is fundamentally important for our understanding of river ecology, but is generally overlooked. We analysed bacterioplankton community composition (BCC) and abundance over 4 mo following an enormous flood event in the Hunter River, Australia, that resulted in a major fish kill. Concentrations of dissolved organic carbon (DOC) and inorganic nutrients ( $\mathrm{N}$ and $\mathrm{P}$ ) were up to 3 times higher during the flood event compared to prior and subsequent months. Bacterial cell abundances were up to 10 times higher at impacted sites during the flood event. Using Automated Ribosomal Intergenic Spacer Analysis we found significant shifts in BCC between the flood impacted month and subsequent months $(\mathrm{p}<0.05)$. Distance linear modelling indicated that DOC and dissolved N and P correlated most strongly with BCC patterns during the high inflow, whereas community dynamics correlated most strongly with nitrogen oxides and ammonium during the river's recovery phase. 16S rRNA amplicon pyrosequencing revealed that common soil-associated and facultative anaerobic genera of Proteobacteria were most dominant during the flood period, suggesting that a proportion of the bacterial community observed during this event were potentially inactive soil microbes transported into the river via terrestrial runoff. During the recovery period, Cyanobacteria and freshwater-associated genera of Actinobacteria and Proteobacteria became dominant in 16S rRNA pyrosequencing profiles. These observations indicate that allochthonous nutrients delivered via floods can significantly stimulate bacterial growth, underpinning substrate-controlled succession of bacterial communities and ultimately shaping the ecology within river ecosystems.
\end{abstract}

KEY WORDS: Bacterioplankton · ARISA $\cdot$ Lotic ecology $\cdot$ Network analyses Resale or republication not permitted without written consent of the publisher

\section{INTRODUCTION}

Riverine ecosystems comprise a variety of ecologically important habitats and support high levels of organism diversity (Arthington et al. 2006, Dudgeon et al. 2006). Underpinning the function, stability and productivity of flowing fresh water (or lotic) ecosystems are the microorganisms that form the base of the food web (Stahl et al. 2006, Blum \& Mills 2012). Microbes including bacteria, phytoplankton and microzooplankton are important drivers of lotic chemical and energy cycles and are abundant and dynamic members of the lotic biota (Havens et al. 2000)

Lotic bacterial communities are biogeographically diverse and are typically characterised by local habi- 
tat-specific endemism, yet are more phylogenetically similar to other freshwater habitats than marine and soil groups (Zwart et al. 2002). Longitudinal gradients in microbial community composition and functional groups are common in rivers and estuaries, as a consequence of changing hydrology and salinity concentrations (Crump et al. 2004, Maranger et al. 2005). Similarly, lotic bacterial community assemblages can shift seasonally, with patterns in bacterial composition typically driven by algal (autochthonous) carbon during low precipitation seasons and by allochthonous carbon during wetter seasons (Almeida et al. 2005, Pinhassi et al. 2006, Hitchcock \& Mitrovic 2013). Compared to marine environments, bacterial abundance, productivity and respiration rates can be significantly higher in lotic systems (Del Giorgio \& Cole 1998, Del Giorgio \& Williams 2005) due to higher nutrient inputs from terrestrial inputs (Cole \& Caraco 2001, Pollard \& Ducklow 2011), and as a consequence riverine ecosystems are often net heterotrophic (Hadwen et al. 2010). Our knowledge of the ecology of lotic microbes is much less developed than our understanding of marine and lake microbial communities. In particular, there is currently limited knowledge of how microbial communities respond to the constantly shifting environmental conditions that are characteristic of river ecosystems (Curtis \& Sloan 2004, Schultz et al. 2013).

Physical and chemical conditions within lotic systems can shift slowly, such as between seasons, or very abruptly, particularly following precipitation events that lead to high inflows and flooding (Westhorpe \& Mitrovic 2012). As the foundation of lotic food webs, microbes are among the first organisms to experience and respond to changes in the dynamic physicochemical environment of rivers and their estuaries (Kirchman et al. 2004, Wear et al. 2013). Understanding how the abundance, composition and function of microbial assemblages change over different temporal scales is fundamental to our understanding of riverine ecology (Blum \& Mills 2012).

Medium to large river inflows, where precipitation events lead to a subsequent increase in flow volume and velocity, are a pivotal regulator of physical habitat and the primary transporter of nutrients in lotic systems (Arthington \& Pusey 2003). They couple abiotic components of terrestrial environments (such as flood plains) with biotic processes in aquatic systems (Junk et al. 1989, Tockner et al. 2000, Sieczko \& Peduzzi 2014). The frequency, variability, volume and quality of river inflows ultimately determine the ecological character of rivers and their associated estuaries (Poff \& Zimmerman 2010). Notably, in many parts of the world, major rivers and estuaries are subject to flow regulation, and receive reduced flow volumes that differ greatly from historical patterns (Vörösmarty et al. 2010). In determining the ecological significance of fresh water inflows, an understanding of natural biological responses to physical changes at the base of lotic food webs is imperative, but currently lacking.

In many aquatic and marine environments, heterotrophic bacterioplankton abundance and activity is tightly regulated by the availability of DOC obtained primarily from autochthonous sources including phytoplankton extracellular exudates and metazoan wastes (Azam et al. 1983, Wilson \& Devlin 2013). However, rivers and estuaries periodically receive large inputs of particulate organic carbon (POC) and DOC from terrestrial (allochthonous) sources during seasonal inflows and floods (Farjalla et al. 2009), and this may temporarily uncouple the reliance of bacterioplankton on autochthonously derived C (Almeida et al. 2005, Ameryk et al. 2005). Such a shift may significantly alter chemical cycling and trophic dynamics within lotic ecosystems over a variety of temporal scales, as has been observed in lake environments (Kritzberg et al. 2004).

When large seasonal floods (that are induced by heavy precipitation events) breach river embankments, floodwaters inundate catchment and floodplains. Organic material from flood-impacted land washes into the river as the water levels recede. Carbon and nutrients then leach from the inundated area, often turning the water a dark tea colour, termed 'black water'. In river systems where considerable land modification has taken place (e.g. cleared pastures), organic carbon and inorganic nutrients accumulate in high concentrations in the flood waters, which contributes strongly to microbial activity and decomposition processes (Carvalho et al. 2003, Almeida et al. 2005, Farjalla et al. 2009). This, in combination with increased turbidity levels that often accompany inflows, can shift the base of the lotic system to a more heterotrophic state (Westhorpe et al. 2010), and in some cases leads to the formation of hypoxic or anoxic zones (Paerl et al. 1998, Zhang et al. 2010). In extreme cases, these low $\mathrm{O}_{2}$ black waters can cause mass mortality in the food web and can detrimentally impact fishery stocks and river ecological health (Salles et al. 2006). The extent of these events will be influenced by changes in composition and activity of microbial populations that follow inflow events.

In marine and lake ecosystems, pulses of organic and inorganic nutrients, derived from a variety of 
biotic (e.g. algal blooms) and abiotic (e.g. nutrient upwelling) events can lead to substrate-controlled succession of bacterial populations (Fawcett \& Ward 2011, Teeling et al. 2012). It is probable that allochthonous resource pulses related to inflow events within rivers will have a similar effect on lotic microbial communities (Wear et al. 2013). Resource variability could then select for copiotrophic microbes which normally persist in low abundances but are capable of very efficient resource assimilation during nutrient pulses. However, to date very few studies have observed these processes in lotic systems.

Previous studies have performed nutrient manipulation experiments using microcosms to investigate heterotrophic bacterial growth response to simulated inflows, floods and their associated nutrient inputs (Hitchcock et al. 2010, Hitchcock \& Mitrovic 2013, Mitrovic et al. 2014). These studies have indicated that heterotrophic bacterial growth in rivers and estuaries is often limited or co-limited by available DOC, $\mathrm{N}$ and $\mathrm{P}$ during periods of low river discharge (Jansson et al. 2006, Hadwen et al. 2010, Hitchcock et al. 2010, Hitchcock \& Mitrovic 2013), but very little is known about how these events influence the composition and diversity of bacterial assemblages, or the implications for lotic chemical cycling and trophic dynamics. This knowledge is of growing importance because there is a global pattern of high flow events being returned to many major coastal rivers and estuaries as a result of flow management (Dudgeon 2010). Here we examined the compositional dynamics of a lotic microbial community during and after a major black water event, with the objective of determining to what extent ephemeral inputs of allochthonous organic material alter the microbial ecology of river ecosystems. tative of many regulated estuaries of the temperate east Australian coast, and has recently had new flow regulation rules assigned to it (NSWDPI 2003).

\section{Sampling regime}

Sampling was conducted at high tide at 7 sites, across the tidal zone of the Hunter River estuary, as well as within its 2 main tributaries (Paterson River and Williams River). Sites 1, 3, 4, 6 and 7 were located in the Hunter River, Site 2 was located within the Paterson River and Site 5 was located in the Williams River (Fig. 1, Table 1). Biological sampling began in March 2013, in conjunction with a monthly water quality sampling regime which had begun in 2012. The first bacterial sampling occasion conducted in March 2013 coincided with an intense inflow where depletion in dissolved oxygen (DO) resulted in a mass fish kill. Following this black water event, sampling continued on a monthly basis until June 2013.

\section{Water sampling protocols}

Hydrographic data were obtained from gauging stations operated by the NSW Office of Water throughout the Hunter River estuary and its catchment. Flow discharge, expressed as mean $\mathrm{ml} \mathrm{d}^{-1}$, was recorded every 15 min over each $24 \mathrm{~h}$ period and converted to mean daily flow by averaging flow discharge across $24 \mathrm{~h}$ intervals. In situ water quality measurements including temperature, pH, conductivity and DO were taken at all sites from $20 \mathrm{~cm}$ below the water surface, using a calibrated Hydrolab

\section{MATERIALS AND METHODS}

\section{Study site}

Sampling was conducted in the Hunter River estuary system, located on the mideastern coastline of New South Wales (NSW), Australia $\left(63.34^{\circ} \mathrm{S}, 37.26^{\circ} \mathrm{E}\right.$ to $\left.63.76^{\circ} \mathrm{S}, 37.91^{\circ} \mathrm{E}\right)$. Hunter River discharge to its estuary is regulated by dams and weirs, and 2 of the Hunter River system's main tributaries - the Williams and Paterson rivers - are also regulated. The Hunter River estuary was chosen as a suitable sample site for this study as it is represen-
Table 1. Site distance from estuary mouth and salinity at each site and sampling occasion in 2013. Data given in practical salinity units (PSU) converted from conductivity in $\mathrm{mS} \mathrm{cm}^{-1}$

\begin{tabular}{|c|c|c|c|c|c|c|}
\hline \multirow{2}{*}{ Location } & \multirow[t]{2}{*}{ Site } & \multirow{2}{*}{$\begin{array}{l}\text { Distance from } \\
\text { estuary mouth }(\mathrm{km})\end{array}$} & \multicolumn{4}{|c|}{ Salinity } \\
\hline & & & Mar & Apr & May & Jun \\
\hline \multirow[t]{6}{*}{ Hunter River } & 1 & 49.1 & $<2$ & $<2$ & $<2$ & $<2$ \\
\hline & 3 & 45.9 & $<2$ & $<2$ & $<2$ & $<2$ \\
\hline & 4 & 35.4 & $<2$ & $<2$ & $<2$ & $<2$ \\
\hline & 6 & 28.1 & $<2$ & $<2$ & 8.8 & 5.8 \\
\hline & 7 & 16.9 & $<2$ & 9.7 & 25.6 & 22.1 \\
\hline & & $\begin{array}{l}\text { Distance from Hunter } \\
\text { River junction }(\mathrm{km})\end{array}$ & & & & \\
\hline Paterson River & 2 & 55.0 & $<2$ & $<2$ & $<2$ & $<2$ \\
\hline Williams River & 5 & 46.0 & $<2$ & $<2$ & $<2$ & $<2$ \\
\hline
\end{tabular}




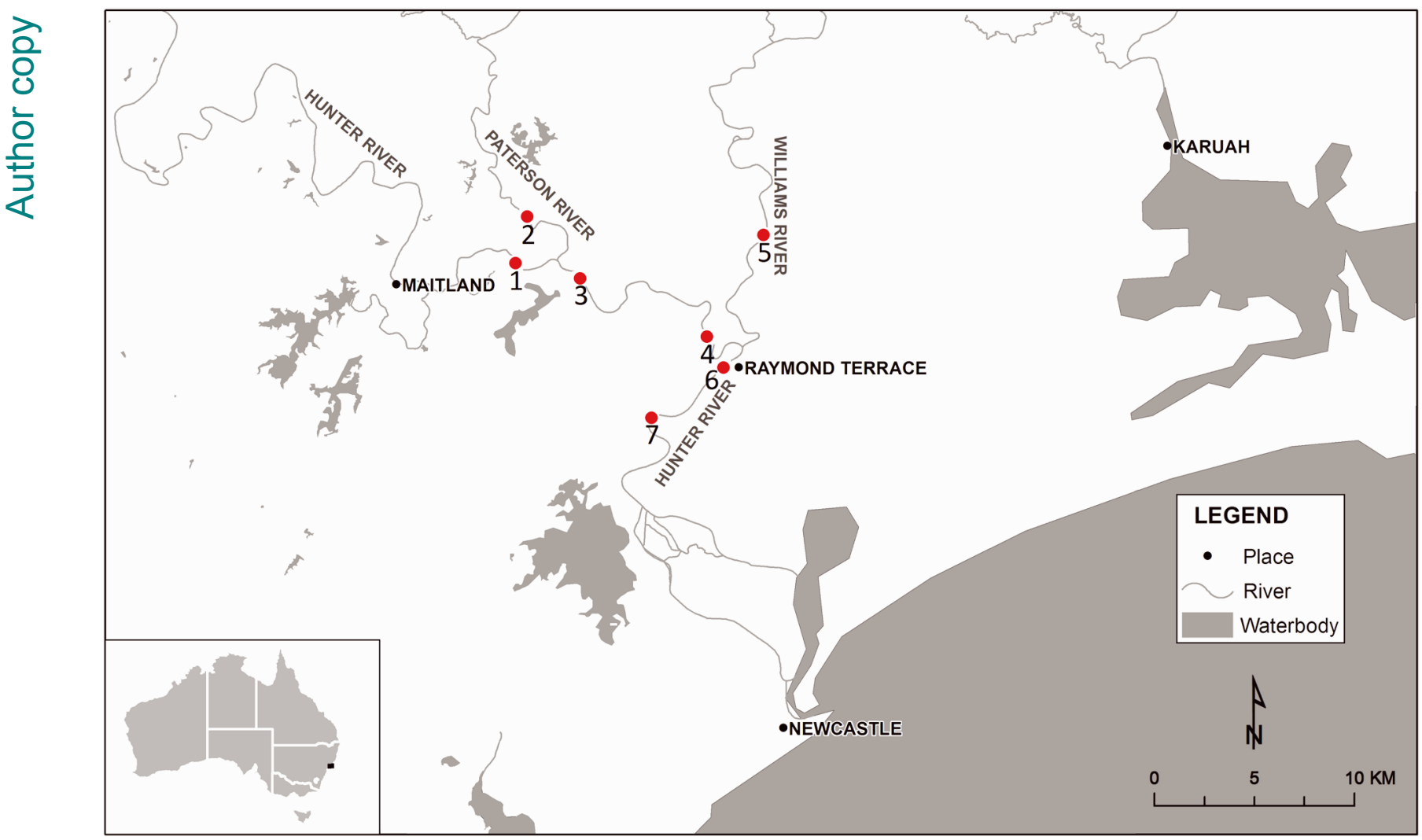

Fig. 1. Sampling sites within the tidal pool of the Hunter River and its 2 main tributaries, the Paterson River and the Williams River, New South Wales, Australia

Surveyor (Hydrolab) and MS5 Sonde probe (Hydrolab). Turbidity measurements were taken using a Hach turbidity Meter (Hach Company).

Surface samples for dissolved organic carbon (DOC) were collected in triplicate and immediately filtered through $0.45 \mu \mathrm{m}$ cellulose acetate filters (Sartorius Stedim Biotech) into pre-combusted $200 \mathrm{ml}$ glass bottles, refrigerated and then acidified with $2 \mathrm{~N}$ hydrochloric acid before analysis on a Shimadzu TOC-VCSH analyser using the High Temperature Combustion Method (Eaton et al. 1995, Westhorpe \& Mitrovic 2012). Nutrient samples $(50 \mathrm{ml})$ were separately analysed for total nitrogen (TN), dissolved organic nitrogen $(\mathrm{DON})$, oxidised nitrogen $\left(\mathrm{NO}_{\mathrm{x}}\right)$, ammoniacal nitrogen $\left(\mathrm{NH}_{4}\right)$, total phosphorus (TP) and filtered reactive phosphorus (FRP). Nutrient samples were filtered through $0.45 \mu \mathrm{m}$ filters, and stored in triple-rinsed $50 \mathrm{ml}$ PET bottles and refrigerated at $4^{\circ} \mathrm{C}$. Analysis was conducted using a segmented flow analyser (OI Analytical Model FS3100) in accordance with standard methods (Eaton et al. 1995).

Chlorophyll a (chl a) concentrations were determined by filtering $200 \mathrm{ml}$ of surface water onto
$0.75 \mu \mathrm{m}$ pore-size glass microfiber filters and were analysed using the methods of Eaton \& Franson (2005).

\section{Bacterial cell enumeration}

Triplicate $1 \mathrm{ml}$ surface samples were fixed with glutaraldehyde ( $2 \%$ final concentration) and snap frozen in liquid nitrogen. Samples were stored at $-80^{\circ} \mathrm{C}$ prior to flow cytometric (FCM) analysis. In preparation for FCM, samples were quickly thawed in hot water and stained with SYBR Green I nucleic acid stain (1:10000 final dilution; Molecular Probes) (Marie et al. 1997, Gasol \& Del Giorgio 2000, Seymour et al. 2005). Fluorescent reference beads (1 $\mu \mathrm{m}$ diameter, yellow/green; Molecular Probes) were added to each sample immediately prior to analyses at a final concentration of $10^{5} \mathrm{ml}^{-1}$. Samples were analysed using an LSRII flow cytometer (Becton Dickinson) and bacterial populations were discriminated according to cell side scatter (SSC) and SYBR Green fluorescence. Data were analysed using WinMDI v. 2.9 software (WinMDI; Joseph Trotter, Salk 
Institute for Biological Studies). Cell concentrations are reported in bacterial cells $\mathrm{ml}^{-1}$.

\section{DNA extraction}

Triplicate 11 surface water samples were collected in rinsed plastic bottles, and filtered using a peristaltic pump onto $5 \mu \mathrm{m}$ and $0.2 \mu \mathrm{m}$ membrane filters arranged in an in-line filtration set up. The $5 \mu \mathrm{m}$ pore size membrane filter was employed to capture bacteria attached to suspended particles (Nair \& Simidu 1987, Gram et al. 2010, Tang et al. 2011, Rösel \& Grossart 2012), allowing discrimination from the free-living bacterial community captured on $0.2 \mu \mathrm{m}$ membrane filters. In the absence of a universally agreed filter size standard appropriate for discriminating attached and free-living bacterial communities, we conservatively selected a $5 \mu \mathrm{m}$ membrane pore size which will allow for the capture of medium to large particles colonised by bacteria (Azam \& Hodson 1977, Acinas et al. 1999, Riemann \& Winding 2001). Filters were immediately snap-frozen in liquid nitrogen, and stored at $-80^{\circ} \mathrm{C}$ until DNA extraction was performed. Extraction of microbial genomic DNA was performed using a bead beating and chemical lysis kit (MoBio PowerWater) according to the manufacturer's directions. Extracted DNA was quantified using a Qubit Fluorometer (Life Technologies).

\section{Bacterial community fingerprinting}

To investigate bacterial community diversity we used Automated Ribosomal Intergenic Spacer Analyses (ARISA) (Brown et al. 2005). PCR was performed using 16S and 23S Internal Transcribed Spacer (ITS) specific primers. These included the 6-carboxyfluorescein (FAM)-labelled forward primer $1392 \mathrm{f}\left(5^{\prime}\right.$-GYA CAC ACC GCC CGT-3') and the reverse primer $23 \mathrm{Sr}$ (5'-GGG TTB CCC CAT TCR G-3') (Sigma-Aldrich). Each $20 \mu \mathrm{l}$ PCR reaction mixture consisted of $2 \mu \mathrm{l}$ of extracted DNA, $10 \mu \mathrm{M}$ of each primer, $10 \mu \mathrm{l}$ of GoTaq ${ }^{\circledR}$ Colorless Master Mix, $\left(2 \times\right.$ : GoTaq ${ }^{\circledR}$ DNA Polymerase supplied in $2 \times$ Colorless GoTaq ${ }^{\circledR}$ Reaction Buffer at $\mathrm{pH} 8.5), 400 \mu \mathrm{M}$ dATP, $400 \mu \mathrm{M}$ dGTP, $400 \mu \mathrm{M} \mathrm{dCTP}, 400 \mu \mathrm{M}$ dTTP and $3 \mathrm{mM} \mathrm{MgCl}_{2}$. This reaction mixture was subjected to a PCR cycle of $94^{\circ} \mathrm{C}$ for $5 \mathrm{~min}$, and then 35 cycles $\left(94^{\circ} \mathrm{C}\right.$ for $40 \mathrm{~s}$, $56^{\circ} \mathrm{C}$ for $40 \mathrm{~s}, 72^{\circ} \mathrm{C}$ for $90 \mathrm{~s}$ ), followed by $72^{\circ} \mathrm{C}$ for 5 min (Brown et al. 2005). Fragments were sized using a 3730xl DNA Analyzer (Applied Biosystems) at the Australian Genome Research Facility (AGRF), using the LIZ1200 internal size.

ARISA profiles were analysed using Peakscanner software (v. 1, Applied Biosystems). Fragments with a relative fluorescence intensity (RFI) $<0.09 \%$ of total amplified DNA were discarded as they are indistinguishable from background noise (Hewson \& Fuhrman 2004). Fragments with $<200$ or $>1200$ base pairs (bp) were also discarded as they fall outside of the internal size standard range. Binning scripts in Custom R statistical software were used to discriminate fragments, whereby fragments differing by less than $2 \mathrm{bp}$ were considered the same operational taxonomic unit (OTU) (Ramette 2009).

\section{S RNA amplicon pyrosequencing}

16S rRNA amplicon pyrosequencing was used to identify and contrast the composition of bacterial communities from the attached $(>5 \mu \mathrm{m})$ and free-living $(>0.2 \mu \mathrm{m},<5 \mu \mathrm{m})$ bacterial populations during the March and April sampling expeditions, allowing us to compare the bacterial community during a black water event (March) to the subsequent recovery phase.

DNA samples were amplified with the 16S rRNA universal Eubacterial primers 27F (5-AGA GTT TGA TCC TGG CTC AG-3') and 519R (5-GTN TTA CNG CGG CKG CTG-3') (Kim et al. 2011, Kumar et al. 2011) and a PCR reaction using the HotStarTaq Plus Master Mix Kit (Qiagen) using the following cycling conditions: $94^{\circ} \mathrm{C}$ for $3 \mathrm{~min}$, followed by 28 cycles of $94^{\circ} \mathrm{C}$ for $30 \mathrm{~s} ; 53^{\circ} \mathrm{C}$ for $40 \mathrm{~s}$ and $72^{\circ} \mathrm{C}$ for $1 \mathrm{~min}$; after which a final elongation step at $72^{\circ} \mathrm{C}$ for 5 min was performed. Post-PCR purification was performed using Agencourt Ampure beads (Agencourt Bioscience). Samples were sequenced using the Roche 454 FLX titanium platform at the Molecular Research Labs (Shallowater, Texas, USA).

DNA sequences were processed using the Quantitative Insights Into Microbial Ecology (QIIME) pipeline (Caporaso et al. 2010) as previously described for 454 pyrosequencing data (Gibbons et al. 2013). Briefly, DNA sequences were de-multiplexed and reads shorter than $200 \mathrm{bp}$, with a quality score $<25$ or containing homopolymers exceeding $6 \mathrm{bp}$ were discarded. OTUs were defined at $97 \%$ sequence identity using UCLUST (Edgar et al. 2011) and assigned taxonomy against the Greengenes database (v. 13.5) (McDonald et al. 2011) using BLAST (Altschul et al. 1990, DeSantis et al. 2006). Chimeric sequences were detected using ChimeraSlayer (Haas et al. 2011) and filtered from the dataset. 


\section{Statistical methods}

Linear correlations between environmental variables and bacterial cell counts were measured by applying Pearson's Correlation Coefficient to data. Determination of variability between flood affected and post-flood months, sites and bacterial filter size classes was achieved by applying a suite of permutational multivariate analysis of variance (PERMANOVA) statistical methods in PRIMER (Primer-E) to environmental and biological (ARISA and pyrosequencing) data. To determine whether environmental conditions and bacterial community composition (BCC) at river sites varied significantly between 'during flood' and 'post flood' periods, PERMANOVA was used to compare the variance in the means of environmental and biological data from the flood impact month of March 2013, to the post flood months of April, May and June 2013 (Anderson 2001). An assumption of PERMANOVA is that data are equally dispersed (Anderson et al. 2007). Unequal dispersion in environmental variable data was tested using draftsman plots. Where unequal dispersion of data was detected, it was resolved by LOG+1 transformation, therefore reducing the skewness of the data while maintaining proportionality and satisfying the assumptions of PERMANOVA.

PERMANOVA with PRIMER + PERMANOVA software v. 6 (Anderson et al. 2007) was used to determine significant dissimilarity within biological (ARISA) and environmental data, between the flood impacted month and subsequent months. Data were then graphically represented using non-parametric multi-dimensional scaling (nMDS) plots. Distance based linear modelling (DistLM), using a stepwise procedure for adjusted $\mathrm{R}^{2}$, was then used to select the environmental variables most likely to explain patterns in the biological data. This was graphically represented by a distance-based redundancy analysis (dbRDA) plot.

A detailed analysis of relationships between environmental variables and specific bacterial taxonomic units was also made using network analysis (Steele et al. 2011). Statistical associations between variables were determined using the maximal information coefficient (Reshef et al. 2011) by selecting the 50 most dominant bacterial genera identified from 28 samples across March and April, using the 16S rRNA amplicon pyrosequencing data and visualized in Cytoscape (Fuhrman \& Steele 2008). All environmental variable and bacterial taxa interactions that were insignificant $(p>0.05)$ or of correlative strength below 0.8 were excluded. The resultant network was created using an edge-weighted force-directed layout which allowed visualisation of the correlation strength between individual bacterial genera and the measured environmental variables (Zhou et al. 2010, Steele et al. 2011). Relationships between variables have been represented by edges, in our network positive associations are represented by black lines and red lines indicate negative associations. The length of the edge relates the strength of correlation between variables, (e.g. shorter edges relate to stronger associations between variables). Variables (including bacterial groups and water chemistry measurements) have been represented by nodes, which have been colour-coded according to the bacterial phyla or environmental variable they belong to, and the size of nodes relates to their relative abundance.

\section{RESULTS}

\section{Physico-chemical dynamics}

We used environmental variable data (including all physical and nutrient measurements) collected during sampling occasions from January 30 until June 12, 2013, which encompassed the physicochemical conditions within the Hunter River estuary under a low flow state (January), during a major inflow event (March), and during the 3 mo recovery phase thereafter (April to June).

During the high flow period in March, flow rates at some sites increased massively from baseline levels of below $300 \mathrm{ml} \mathrm{d}^{-1}$ to in excess of $90000 \mathrm{ml} \mathrm{d}^{-1}$. Since flow rate recordings began in this region in 1968, on average there have only been 1 to 2 events of this magnitude occurring each decade (http:// realtimedata.water.nsw.gov.au/water). Strong linear correlations were identified between mean river discharge rates and water turbidity $(\mathrm{r}=0.66)$ and DOC $(\mathrm{r}=0.84)$, with DOC concentrations peaking in March during the high inflow event (Fig. 2). Flow discharge also correlated strongly with FRP $(\mathrm{r}=0.79)$ and DON $(r=0.77)$, which were both also elevated in March (Fig. 2). Conversely, $\mathrm{NO}_{\mathrm{x}}$ concentrations were lowest in March at Hunter River Sites 3, 4, 6 and 7 and Site 2 on the Paterson River (Fig. 2). Dissolved oxygen (DO) concentrations fell to anoxic levels during the March inflow event with the exception of Site 5, on the Williams River, which was relatively unaffected by the flood. During this period DO dropped to $<0.2 \mathrm{mg} \mathrm{l}^{-1}$ at Sites 2, 3, 4, 6 and 7, but remained above $4 \mathrm{mg} \mathrm{l}^{-1}$ at the upper Hunter River (Site 1). DO concentrations subsequently returned to pre-March 
inflow levels of between 5 and $10 \mathrm{mg} \mathrm{l}^{-1}$ across all sites by the next sampling effort in April. $\mathrm{NH}_{4}$ concentrations were highest at all sites except on the Williams River (Site 5), in April.

Using the entire suite of water chemistry and nutrient parameters measured, significant variation was observed in physical conditions, between months $\left(\mathrm{df}_{3,27}\right.$, perm $_{998}$; pseudo- $\left.F=10.98, \mathrm{p}<0.001\right)$ and sites $\left(\mathrm{df}_{6,27}\right.$, perm $_{996} ;$ pseudo- $\left.F=2.05, \mathrm{p}<0.005\right)$, indicative of a highly dynamic aquatic environment. Although some parameters were dispersed homogenously, (PERMDISP $\mathrm{p}>0.05$ ), the strength of significance $(p<0.01)$ in variation between months and sites (Fig. 2) suggests that the major inflow event in March was a strong driver of spatiotemporal heterogeneity in the physical condition of the Hunter River ecosystem.

\section{Chl a concentrations}

Chl a varied considerably between months and sites, typically ranging between 2 and $40 \mu g \mathrm{l}^{-1}$, with 2 exceptions where phytoplankton blooms were evident: Site 5 in March (83.3 $\left.\mu \mathrm{g} \mathrm{l}^{-1}\right)$, and Site 4 in June $\left(94.3 \pm 0.88 \mu \mathrm{g} \mathrm{l}^{-1}\right)$ (see Appendix 1). Chl a concentrations were generally lower at impacted sites during the flood event in March and higher during the recovery phase in April through to June. Chl a concentration exhibited weak, negative linear correlations with discharge $(\mathrm{r}=-0.26)$ and FRP ( $r=-0.31)$, and was positively correlated with DO $(\mathrm{r}=0.47)$ and $\mathrm{NO}_{\mathrm{x}}(\mathrm{r}=$ $0.20)$.

\section{Bacterial abundance}

Bacterial cell concentrations were highest at all sites in March during the inflow event, with the exception of Site 1 (Hunter River) and Site 5 (Williams River). Across the entire time-series, bacterial cell abundance was highest at Site 2 on the Paterson River in March $\left(2.79 \times 10^{8} \pm 1.12 \times 10^{7}\right.$ cells ml $\left.{ }^{-1}\right)$ and lowest at Site 7 on the Hunter River in June $\left(7.57 \times 10^{6} \pm 6.26 \times 10^{4}\right.$ cells $\left.\mathrm{ml}^{-1}\right)$. Comparison of bacterial cell abundances during the flood period in March to subsequent months using PERMANOVA revealed significant $(\mathrm{p}=0.001)$ and strong $\left(\mathrm{df}_{1,27}\right.$, perm 997 ; pseudo- $F=31.504$ ) temporal dissimilarity between the flood impacted month and subsequent months, which is consistent with bacterial cell concentrations being up to an order of magnitude higher in March compared to the following months.

\section{Bacterial community fingerprinting}

BCC, determined using ARISA, was distinctly different in March during the flood event compared to the recovery period over the 3 subsequent months.
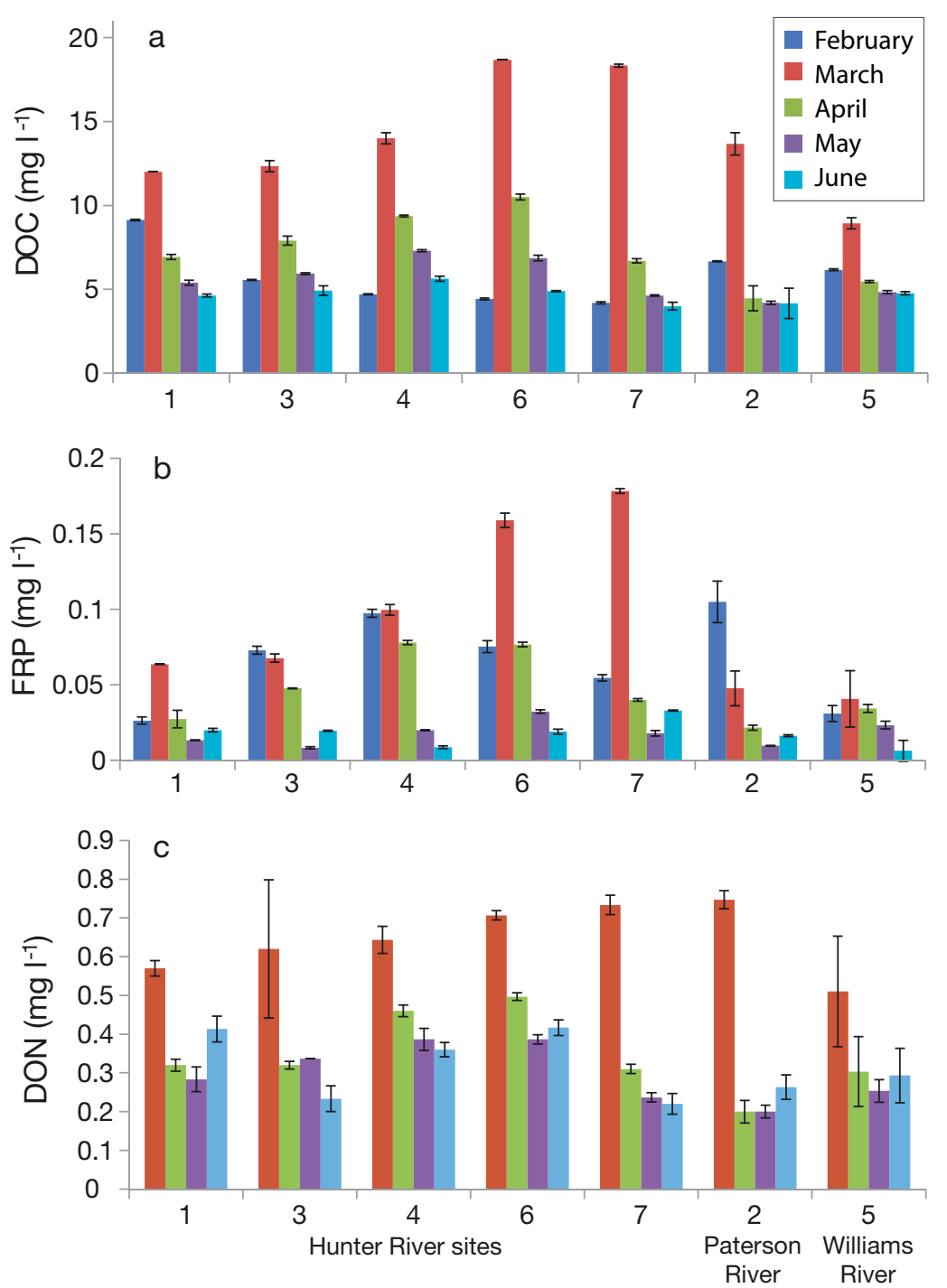

Fig. 2. Nutrient concentrations sampled at the Hunter River (in upstream to downstream sequence, Sites 1, 3, 4, 6 and 7, left to right) and tributary sites (Paterson River, Site 2; Williams River, Site 5) from February to June 2013. (a) Dissolved organic carbon (DOC), (b) filtered reactive phosphorus (FRP), and (c) dissolved organic nitrogen (DON). Error bars represent SE 


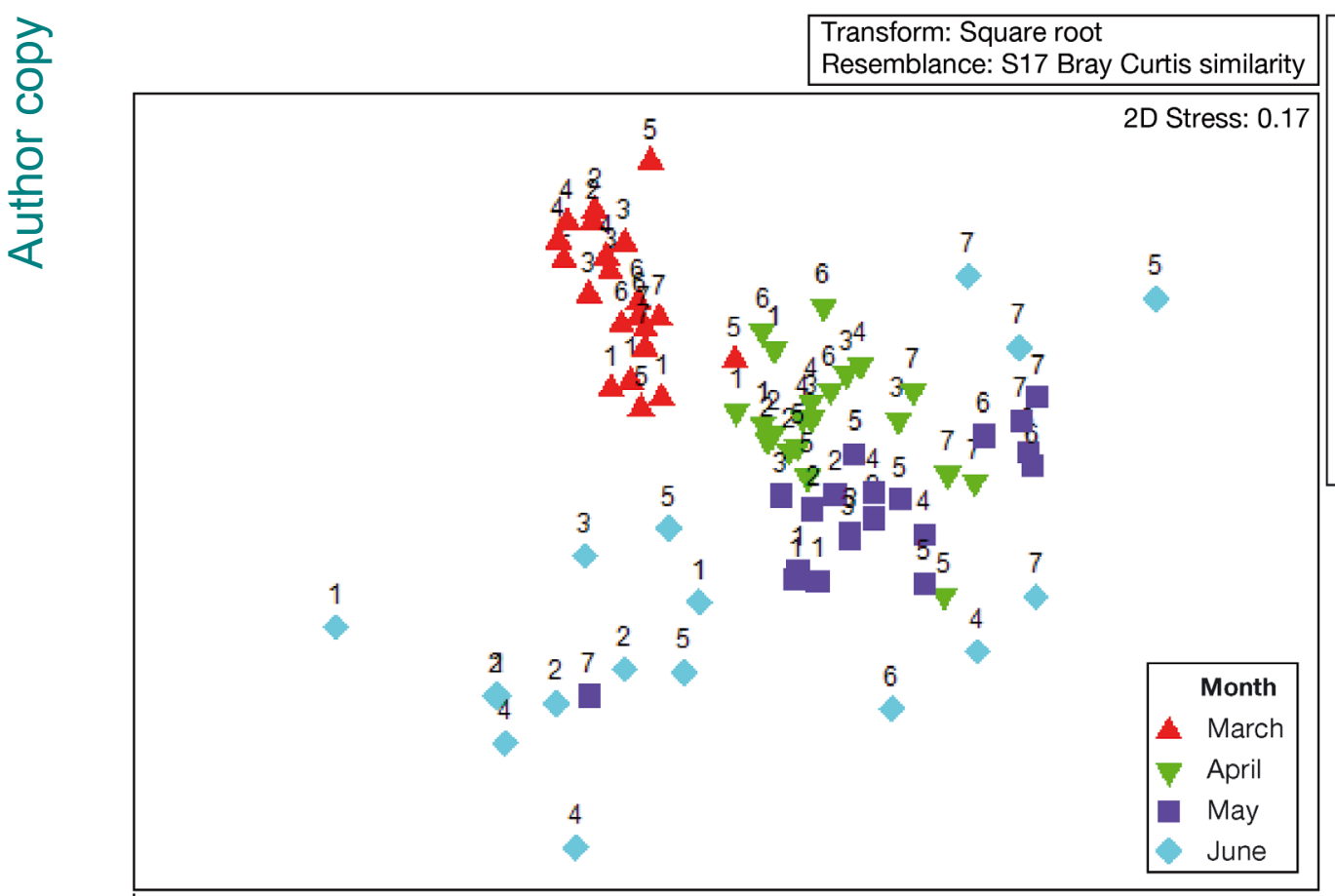

Site 1. Upper Hunter River, upstream of Paterson River confluence

Site 2. Paterson River

Site 3. Upper Hunter River, downstream of Paterson River confluence

Site 4. Upper Hunter River, upstream of Williams River confluence

Site 5. Williams River

Site 6. Hunter River downstream of

Williams River confluence

Site 7. Hunter River, 16.9 km from estuary mouth

Fig. 3. Multi-dimensional scaling (MDS) plot of square root transformed ARISA data for bacterial community composition from March to June 2013. Plots are colour-coded by month and labelled by site. March, coded in red, is tightly clustered and dissimilar from all other months

PERMANOVA assumptions of normality were met (PERMDISP $\mathrm{p}<0.05$ ) and the patterns in ARISA data revealed a significant $(\mathrm{p}=0.001)$ month and site interaction $\left(\mathrm{df}_{18,78}\right.$, perm ${ }_{999}$; pseudo- $\left.F=2.76\right)$. BCC shifted very strongly between the flood-impacted month (March) and subsequent recovery months $\left(\mathrm{df}_{1,78}\right.$, perm $_{997 i}$ pseudo- $\left.F=2.18, \mathrm{p}=0.001\right)$, supported by tight clustering of months and separation of March sites using non-metric MDS (Fig. 3). DOC, FRP and DON, which were at elevated concentrations during the high inflow period of March (Fig. 2), correlated most strongly with community-scale shifts in bacterial community assemblage observed in the ARISA data (Fig. 4). Diminished turbidity levels and higher $\mathrm{NO}_{\mathrm{x}}$ concentrations were also associated with temporal shifts in BCC (Fig. 4).

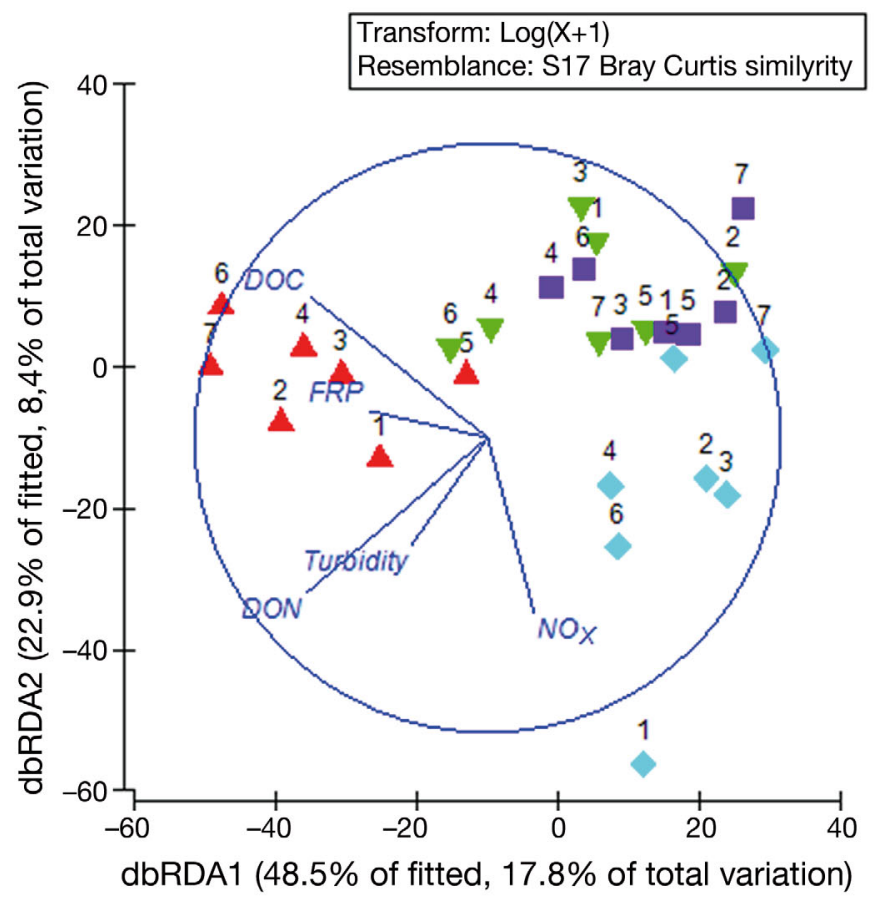

Fig. 4. Distance-based Redundancy Analysis Plot using square root transformed ARISA data, showing March bacterial communities, coded in red, strongly influenced by dissolved organic carbon (DOC) and filtered reactive phosphorus (FRP), and subsequent months influenced by low turbidity, dissolved organic nitrogen (DON) and oxidized nitrogen $\left(\mathrm{NO}_{\mathrm{x}}\right)$ 


\section{Bacterial phylogenetic composition}

16S rRNA amplicon pyrosequencing revealed significant shifts in the bacterial community between the flood-impacted conditions in March to the recovery period in April (Fig. 5). In March, the Proteobacteria represented over $75 \%$ of bacterial sequences across all sampling sites (Fig. 5a), and this group was comprised predominantly of $\beta$-Proteobacteria, which made up $69 \%$ of proteobacterial sequences, followed by the $\varepsilon$-Proteobacteria (12\%) and $\gamma$-Proteobacteria (9\%) (Fig. 5c). On the other hand, during April, Proteobacteria only comprised $25 \%$ of the total bacterial community (Fig. 5b), pr marily as a consequence of strong increases in the relative abundance of Cyanobacteria (27\%) and Actinobacteria (26\%) (Fig. 5b). Furthermore, within April there was a shift in the composition of the Proteobacteria, with a decrease in the $\beta$-Proteobacteria $(43 \%)$ relative to the $\gamma$-Proteobacteria $(30 \%)$ and $\alpha$ Proteobacteria (24\%) (Fig. 5d).

In terms of spatial patterns, $\beta$-Proteobacteria sequences were the most abundant proteobacterial group across all Hunter River and tributary sites (Fig. 6). In the Hunter River, the abundance of $\gamma$-Proteobacteria increased longitudinally in April from the upper Hunter River sites (Sites 1 and 3) to down river sites (Sites 4 and 6) (Fig. 6c), while $\alpha$-Proteobacteria were most abundant at Site 7 closest to the estuarine mouth, where they comprised half the proteobacterial abundance (Fig. 6d). The composition of Proteobacteria in Paterson and Williams rivers differed in March, whereby the $\varepsilon$-Proteobacteria comprised over $30 \%$ of the community at Site 2 in the Paterson River, but was virtually absent at Site 5 in the Williams River (Fig. 6b).

Proteobacterial profiles in the Hunter River and its tributaries also differed between free-living and particle-attached bacterial size classes. Most notably, the abundance of $\varepsilon$-Proteobacteria was greatest in the free-living community in the Paterson River in March and also at Hunter River sites downstream of the Paterson River (Fig. 6b). The relative importance of $\gamma$-Proteobacteria was greatest in the particle-attached communities in April where they comprised over half of the sequences across all Hunter River and tributary sites, with Site 7 (closest to the estuary mouth) being the only exception (Fig. 6c). At this time, the $\alpha$-Proteobacteria comprised over $50 \%$ of the total proteobacterial abundance in both filter size classes at Site 7 (Fig. 6c,d).
At a finer taxonomic resolution, the dominant sequences matching Proteobacteria in both filter size classes in March belonged to the family Comamonadaceae, and the genera Limnohabitans, C39, Acinetobacter and Sulforospirillum (Fig. 7a,b). By April, the large size class was dominated by Cyanobacteria, including Planktothrix and Synechococcus (Fig. 7c), and the smaller size class was strongly represented by ACK-M1 within the Actinobacteria phylum, which replaced the Proteobacteria as the dominant members of the aquatic microbial community (Fig. 7d).

Network analysis revealed that the frequency of sequences matching Proteobacteria in March was associated with the elevated nutrient concentrations during the inflow event (Fig. 8). DOC concentration was strongly and positively correlated with sequences matching Dechloromonas, Acinetobacter,
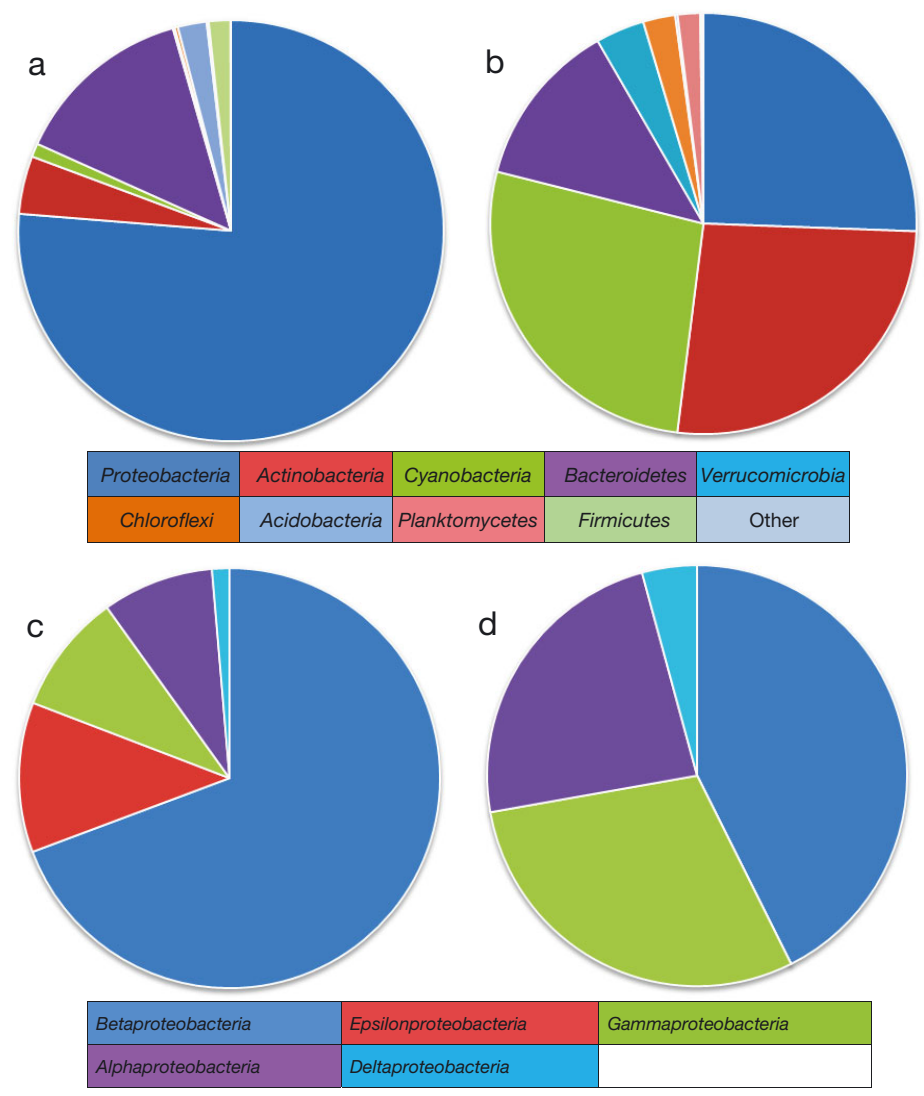

Fig. 5. Comparison between the $(\mathrm{a}, \mathrm{c})$ flood-affected period in March and $(b, d)$ recovery period in April. Bacterial community composition data were produced by combining and averaging the sequence data from the 5 and $0.2 \mu \mathrm{m}$ filter size classes. Total bacterial community composition at the phylum level in (a) March and (b) April, and Proteobacteria at the class level in (c) March and (d) April 
a

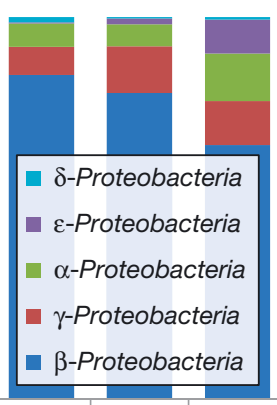

1

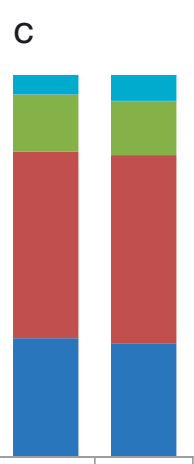

1

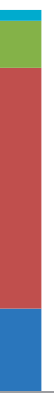

March attached bacteria
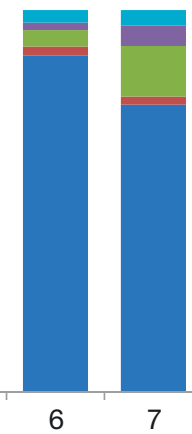

April attached bacteria

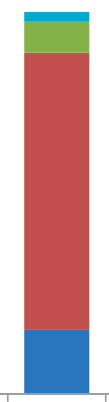

6

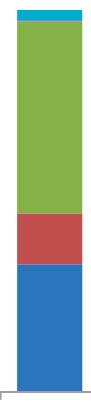

7
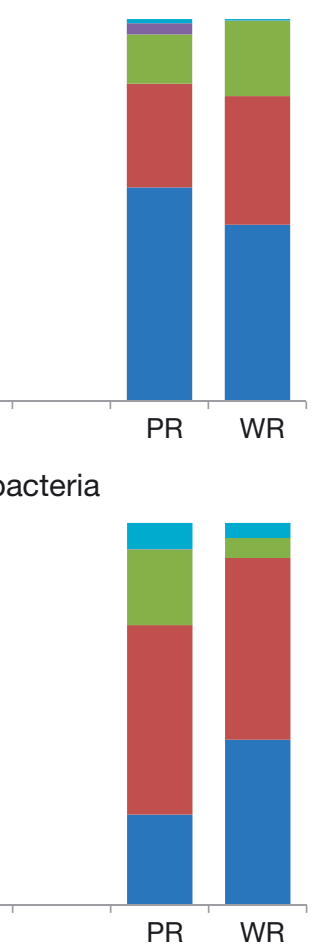

b

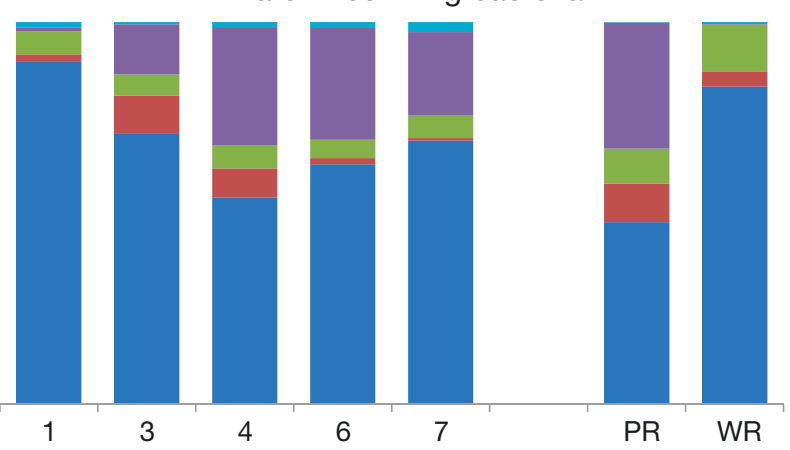

d

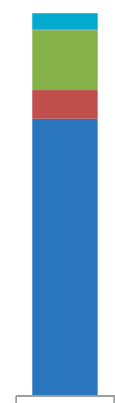

1

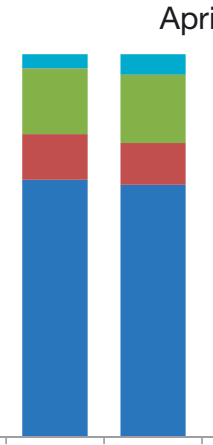

3
March free-living bacteria

April free-living bacteria

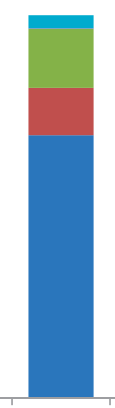

6

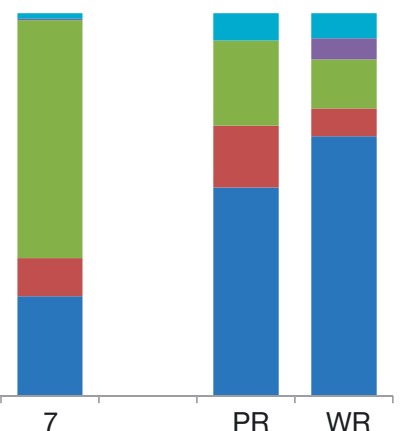

PR WR

Fig. 6. Comparison of Proteobacteria community composition and attached and free-living communities between March and April 2013 using 454 pyrosequencing data. Proteobacteria composition of attached bacteria in (a) March and (c) April, and Proteobacteria composition of free-living bacteria in (b) March and (d) April. PR: Paterson River (Site 2); WR: Williams River (Site 5)

KD1-23 and Limnohabitans (Fig. 8). Similarly, sequence matches to other Proteobacteria including Dechloromonas, Hydrogenophaga and C39 were strongly and positively correlated with concentrations of DON (Fig. 8). Several sequences matching genera of Bacteroidetes, although in relatively lesser frequency to Proteobacteria, shared close association with flood-related organic nutrients, such as DOC, DON as well as turbidity. These include Bacteroidales, Paludibacter, Flavobacterium and sequences matching the family Flavobacteriaceae. Chl a concentration and the abundance of sequences matching Cyanobacteria (Planktothricoides and Synechoccus) were negatively correlated with environmental parameters characteristic of the flood event in March, particularly turbidity and DON, while positively correlated with $\mathrm{NO}_{x}$ and $\mathrm{NH}_{4}$, respectively, which were in greater concentration during the recovery months of April to June. Taken in its entirety, the network in Fig. 8 illustrates the contrast between bacterial taxonomic groups and their nutrient associations. Genera of Proteobacteria and some Bacteroidetes were most commonly and strongly associated with the elevated organic nutrients that characterised the river condition during the flood in March, and chl a concen- trations and Cyanobacteria were negatively associated with environmental conditions typical of flood conditions.

\section{DISCUSSION}

Recent studies within Eastern Australian coastal river and estuarine freshwater inflows have measured patterns in bacterial abundance and biomass, and have revealed a common positive correlation between the import of allochthonous DOC and inorganic nutrients and these parameters (Hitchcock et al. 2010, Hitchcock \& Mitrovic 2013, 2014). We have expanded upon these observations by identifying shifts in BCC and taxonomic diversity in response to an inflow event and have related these changes to the input of allochthonous $\mathrm{C}$ and inorganic nutrients. Our data revealed that shifts in community composition were strongly correlated with specific water chemistry parameters including DOC, DON and FRP, and that specific phylogenetic groups of bacteria were possibly transported from terrestrial or sediment substrate into the river or promoted or suppressed by the physicochemical conditions experienced during the 

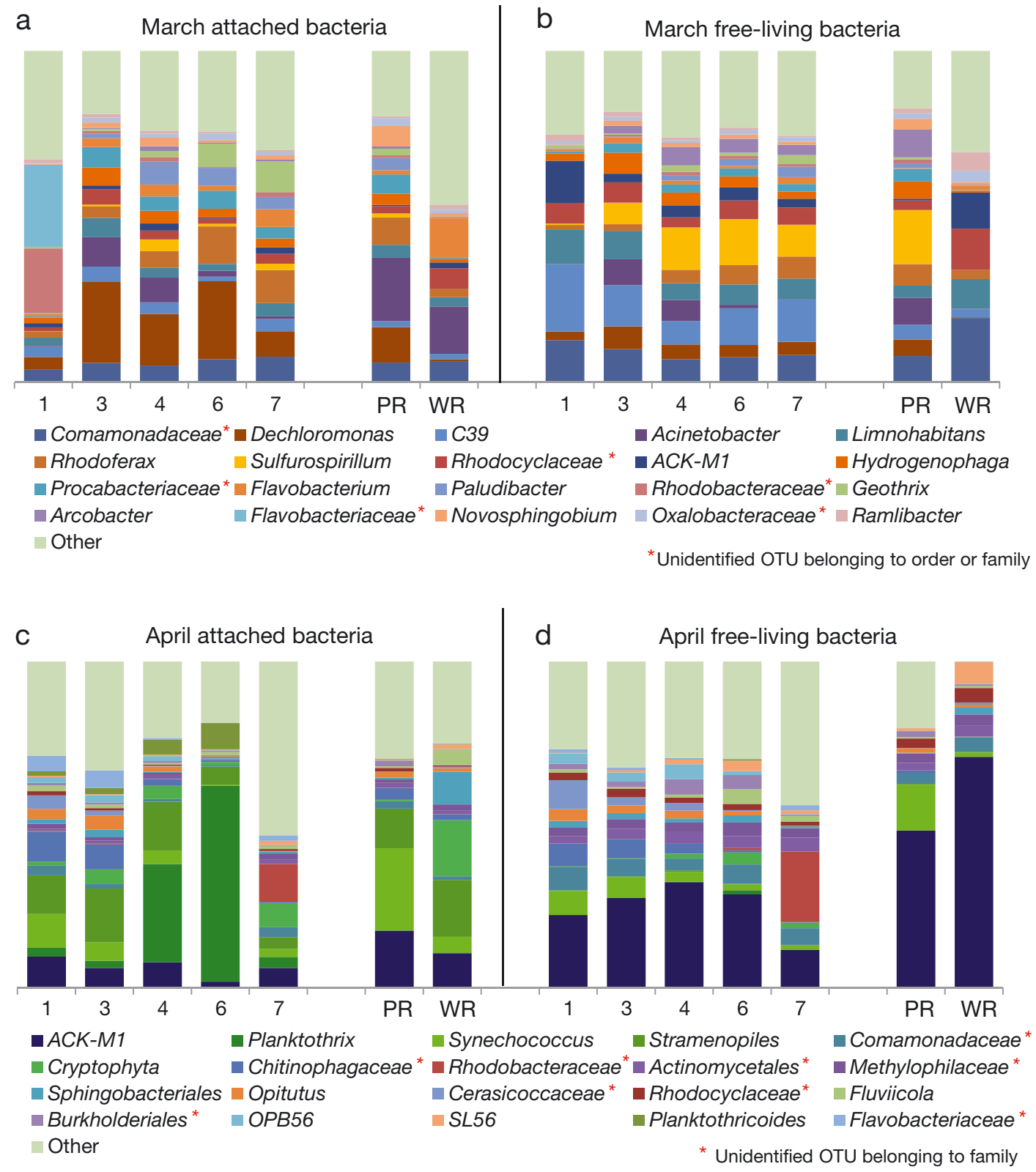

Fig. 7. Bacterial community operational taxonomic units (OTUs) clustered at $97 \%$ similarity and identified down to genus level where possible, using 454 pyrosequencing data. OTU diversity of attached communities in (a) March and (c) April, and OTU diversity of free-living communities in (b) March and (d) April. PR: Paterson River (Site 2); WR: Williams River (Site 5)

flood, while others emerged as dominant community members under the post-flood conditions.

High inflows following precipitation events transport allochthonous material into river and estuarine systems, shifting the dominant carbon and nutrient sources for bacteria from autochthonous-derived (phytoplankton exudates and zooplankton detritus) material, to labile allochthonous DOC (Sinsabaugh \& Findlay 2003, Webster \& Harris 2004, Farjalla et al. 2009, Petrone et al. 2009, Westhorpe \& Mitrovic 2013). Evidence from nutrient addition experiments suggests that changes in resource composition and physical conditions can temporarily uncouple bacterial dependence on autochthonous sources of carbon (Kritzberg et al. 2004, Pinhassi et al. 2006, Hitchcock et al. 2010, Hitchcock \& Mitrovic 2013). This is potentially reflected in our data, where we observed increased bacterial abundance, and community-scale and taxon-specific shifts within the bacterial community, which correlated with shifts in the physical condition of the Hunter and Paterson rivers during and following a high inflow event. 


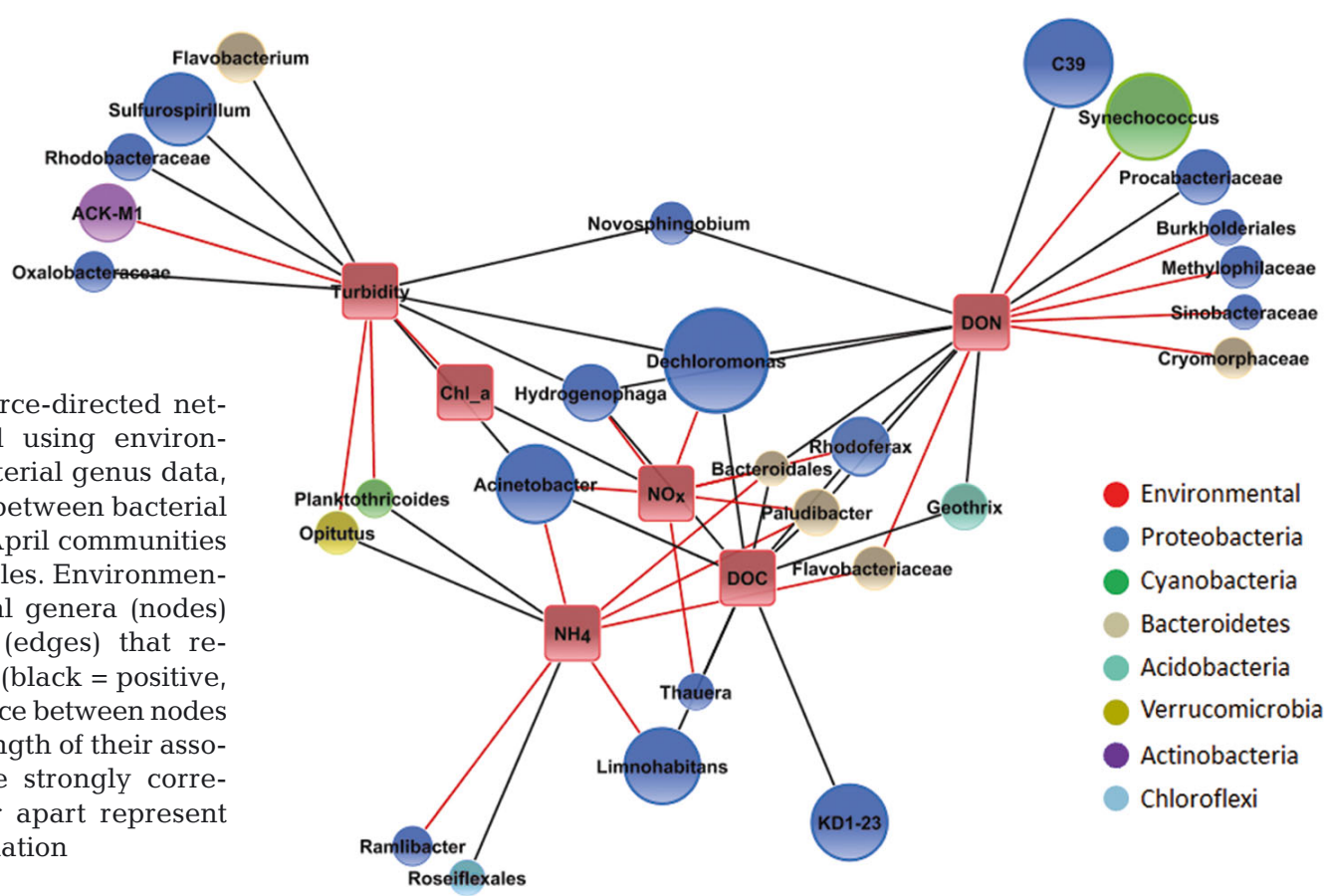

Fig. 8. Edge-weighted force-directed net work analysis generated using environmental variables and bacterial genus data, showing the associations between bacterial genera from March and April communities and environmental variables. Environmen tal variables and bacterial genera (nodes) are connected by lines (edges) that represent their correlations (black $=$ positive red $=$ negative). The distance between nodes corresponds with the strength of their association. Closer nodes are strongly correlated while those further apart represent weaker correlation

\section{Changes in physical and chemical conditions during inflow events}

We found that shifts in water chemistry at sites in the Hunter River and its tributary (the Paterson River) were strongly influenced by the March inflow and black water event. A significant increase in organic nutrients (DOC and DON) and FRP was observed in the Hunter and Paterson rivers. Up to 8-fold increases in DOC concentrations have been observed during flood conditions in river and estuarine systems (Westhorpe \& Mitrovic 2012), and we observed DOC concentrations in the Hunter River to increase from less than $5 \mathrm{mg} \mathrm{l}^{-1}$ to above $15 \mathrm{mg} \mathrm{l}^{-1}$ at Sites 3, 4, 6 and 7 .

In contrast to all other sites, Site 5 on the Williams River received a much reduced inflow, and consequently did not experience the increases in nutrients or shift in DO that were observed at the other sites. Nutrient loads and composition vary between different catchments and floodplains due to hydrologic and geographic variability (Dalzell et al. 2007), and impoundments impair the transport of sediments and particulates (Baldwin et al. 2010), which may explain why the Williams River did not receive the same nutrient loads as the Hunter and Paterson rivers. The lack of inflow effects at Site 5 are likely a consequence of the presence of a weir and the discrete properties of the Williams River watershed. Due to the stability of chemical conditions at Site 5, this site effectively acted as a negative control when considering the shifts in microbial communities observed in this study.

\section{Changes in bacterial abundance associated with inflow events}

Both DOC and inorganic nutrients limit microbial growth in rivers and estuaries during low basal flows (Pinhassi et al. 2006, Hitchcock \& Mitrovic 2013). The increase in $\mathrm{C}, \mathrm{N}$ and $\mathrm{P}$ concentrations (DOC, TP, FRP, TN and DON) during the high inflow period coincided and possibly led to a significant increase in bacterial abundance, as has been observed in several micro-mesocosm nutrient addition experiments (Jansson et al. 2006, Pinhassi et al. 2006, Hitchcock et al. 2010, Hitchcock \& Mitrovic 2013). Bacterial abundance at impacted sites during March was up to an order of magnitude higher (at $>10^{7}$ cells $\mathrm{ml}^{-1}$ ) compared to the non-impacted Site 5 or subsequent months (April to June).

Carbon and nutrient concentrations returned to levels that resembled pre-flood conditions by the next sampling occasion in April (1 mo post inflow event). During this period, bacterial concentrations also declined substantially. These patterns reflect the capacity of riverine bacteria to rapidly utilise allochthonous pulses of dissolved organic matter during flood conditions. 


\section{Changes in bacterial community composition during inflow events}

Analyses of our ARISA data revealed that the changes in bacterial abundance between inflow and post inflow periods were accompanied by a significant shift in BCC. The dissimilarity in bacterial community assemblage was far greater between March and April, compared to dissimilarity between subsequent months, indicating that the inflow event in March profoundly altered bacterial communities beyond normal month-to-month variations. Distance linear modelling revealed that shifts in the composition of bacterial communities coincided with increased concentrations of organic and inorganic nutrients. This is suggestive of a community change related to growth responses to allochthonous nutrient inputs by copiotrophic bacteria (Palijan et al. 2008). However, there is also the possibility that the links between imported nutrients may reflect a coincidental link between water chemistry and allochthonously introduced microbes advected from adjacent floodplains, riparian zones and sediments (Miletto et al. 2008).

Notably, in addition to driving temporal variability in the composition of microbial communities, the March flood event also influenced the degree of spatial structure in microbial assemblages across the study region. Spatial homogeneity of bacterial communities in the Hunter and Paterson rivers was highest during the inflow event, and communities became more spatially heterogeneous over the 3 subsequent post inflow event months. This pattern indicates that the flood event acted to remove niche partitioning of microbial communities by homogenizing physical and chemical conditions across the Hunter River ecosystem, a process that may have further, previously unconsidered, ecological consequences. In addition, the advection of microbes from riparian and adjacent terrestrial sources may have contributed further to the apparent spatial similarity of $\mathrm{BCC}$ during the flood period. We suggest that the massive input of freshwater from the upper-river catchment and adjacent terrestrial zones during the flood temporarily reduced the influence of localised factors on water chemistry and biological composition of the Hunter River, which during low inflow periods would typically underpin spatial heterogeneity. In addition, the impacts of high inflow rates likely diminished tidal influence and led to reduced salinity concentrations in the estuarine portion at Sites 6 and 7 (from brackish to fresh), resulting in the more spatially homogenous physical and chemical envi- ronment, and bacterial distributions. However by April, the re-establishment of longitudinal physicochemical gradients - ascending from upper river to down river sites (as seen in Fig. 2), likely led to the development of a longitudinal biological gradient resulting in a more spatially heterogeneous estuarine bacterioplankton community. This is indicated by the wider distribution of June data points in Fig. 3 as the impacts driven by the flood event dissipated throughout the recovery months, which is perhaps more typical of low inflow periods.

Although less pronounced in the ARISA profiles, 16S rRNA data indicated that the bacterial community at Site 5 in the Williams River differed to floodimpacted sites during March. Specifically, the $\varepsilon$ Proteobacteria that were present at flood-impacted sites (Sulfurospirillum in particular) were virtually absent at the Williams River site in March, which had a greater proportion of freshwater bacteria compared to the flood-impacted tributary. This suggests that, consistent with the smaller shifts in physicochemical conditions at this site, the bacterial community at Site 5 was less influenced by the flood event than the other tested sites. Notably, the differences between Site 5 and the other sites were much more evident in 454 pyrosequencing data than the ARISA data, and are likely a result of the greater sensitivity of 454 pyrosequencing relative to ARISA.

Patterns in the 16S rRNA data were indicative of a shift in the microbial assemblage from a heterotrophdominated community during the flood event, to a community with a higher proportion of autotrophic microbes in the recovery period. In April the relative proportion of sequences matching cyanobacteria was higher than during the flood event in March. A likely explanation for this pattern is the very high turbidity levels that occurred during the flood period, which will result in limited light availability to phototrophic microbes. The reduction in cyanobacteria sequences in March was mirrored by a decrease in total chlorophyll. In addition to the input of organic carbon during the flood, the turbid conditions experienced in March will have further assisted heterotrophic bacteria to outcompete phototrophs for common limiting inorganic nutrients (Almeida et al. 2005, Ameryk et al. 2005). This pattern was supported by the network analysis which revealed that the high levels of chemo-lithotrophic and chemoorganotrophic organisms, including Sulfurospirillum, ACK-M1, Dechloromonas and Acinetobacter, were strongly positively correlated with turbidity levels.

An additional driver of bacterial community patterns which likely influenced BCC in March was ter- 
restrial run-off following the heavy rainfall, transporting soil and soil-associated microbes into the river water column. Sequences matching soil- and sediment-associated, chemo-lithotrophic specialist sulphate reducers and sulphur-oxidising bacteria including Acinetobacter (Newton et al. 2011), Dechloromonas and Sulfurospirillum (Kelly et al. 2005) comprised a major portion of the most abundant bacterial genera in the water column in March, across all flood-affected sites for both filter size classes. Network analyses indicated that these groups of bacteria were positively correlated with flood conditions, including increased concentrations of DOC, DON and turbidity levels. The decreases in DO, and links to bacterial abundance and specific OTUs observed here, could be related to either the increased abundance and activity of lotic microbes occurring as a consequence of organic and inorganic nutrient inputs, or the rise in bacterial biomass associated with allochthonous inputs of terrestrial bacteria into the system.

Endemic freshwater bacteria also responded to the flood conditions in March. Sequences matching fresh water chemo-organotrophic bacteria including Limnohabitans, ACK-M1 and C39 were abundant in the $0.2 \mu \mathrm{m}$ filter size class (representing the small cell sized and free-living bacteria) in March, which is consistent with previous observations that these organisms are capable of efficient assimilation of organic carbon and inorganic nutrients facilitating rapid growth in response to terrestrial water intrusions (Hahn et al. 2010, Lin et al. 2012).

In April, as the physical condition of the Hunter and Paterson river systems returned to a pre-flood state (i.e. it transitioned from an anoxic, turbid and highly eutrophic system during the flood to an aerobic, low turbidity and decreased nutrient state), substantial shifts in the composition of bacterial communities occurred. The relative importance of the Proteobacteria decreased significantly from March to April and this shift in total abundance was accompanied by a significant change in the composition of this group. The patterns observed here are consistent with previous studies that found Proteobacteria to be numerically dominant in river and lake habitats when bacterial communities are supported by allochthonous nutrient inputs, and to be less abundant when autochthonous nutrients are most important (Tang et al. 2009, Schultz et al. 2013). Most notably in March, $\beta$-Proteobacteria dominated both filter class communities. This group comprised cosmopolitan, freshwater bacteria belonging to the Comamonodaceae family and the genus Limnohabitans (Crump \&
Hobbie 2005), in addition to the Dechloromonas genus, a group previously identified as soil-dwelling bacteria (García-Armisen et al. 2014). ع-Proteobacteria were the second most abundant Proteobacteria in the free-living Hunter and Paterson river sites in March, consisting exclusively of bacteria belonging to the Sulfurospirillum genus, which has previously been observed to thrive in micro-aerophyllic, hydrocarbon-contaminated conditions (Rossi et al. 2012). We suggest that the Proteobacteria composition observed in March is indicative of both a numerical increase in endemic freshwater bacteria as a result of allochthonous organic nutrient inputs, and the transport of bacteria from soil and sediment environments into the river. During April, while the $\beta$-Proteobacteria was still abundant, a substantial increase in the proportion of $\gamma$-Proteobacteria $(30 \%)$ and $\alpha$-Proteobacteria groups was observed. The increase in $\gamma$-Proteobacteria was not represented by a single dominant group but accumulatively by several low abundance groups. Conversely, $\alpha$-Proteobacteria belonging to the Rhodobacteraceae family was more abundant in Hunter River sites closest to the estuary mouth. These observations are consistent with typical planktonic microbial communities widely reported in marine and brackish estuarine environments (Liao et al. 2007, Pujalte et al. 2014). We suggest that the change in community structure and increase in spatial heterogeneity of bacterial assemblages in April were influenced by reduced freshwater inflow, allowing the reestablishment of a longitudinal salinity gradient across the tidal pool.

We employed 2 filter size classes to discriminate bacterial sub-communities between large and attached cells, which were retrieved on the $5 \mu \mathrm{m}$ filter, and small and free-living cells, collected on the $0.2 \mu \mathrm{m}$ filter. The large filamentous cyanobacteria Planktothrix, and small but abundant single-celled cyanobacteria Synechococcus were among the most abundant organisms collected on the large filter size during April. The occurrence of the large filamentous cells (up to $8 \mu \mathrm{m}$ in diameter) (Entwisle et al. 1997) in this filter size class is as anticipated, but the occurrence of Synechococcus in this filter size, particularly in the estuarine Sites 6 and 7 during April, is likely explained by colonisation of suspended particles (Crespo et al. 2013, Thiele et al. 2014). Planktothrix and Synechococcus are obligate photoautotrophs, and their distribution and abundances across river, estuary and coastal environments are regulated by the availability of inorganic nutrients (Partensky et al. 1999, Halstvedt et al. 2007). The post-flood conditions of the Hunter and Paterson rivers were con- 
ducive for Plankothrix and Synechococcus growth, whereby these organisms presumably exploited the elevated light levels and concentrations of remineralised nutrients during this period. Network analysis revealed that phototrophic genera were negatively associated with the conditions during the flood period and likely promoted by elevated inorganic nitrogen post flood in April. In addition there was a substantial increase in the relative importance of the actinobacterial group $A C K-M 1$ which has been observed in freshwater environments to have a strong chemotactic response to ammonium (Dennis et al. 2013) and be in high abundance during eutrophic conditions (Van der Gucht et al. 2005). Network analysis indicated that reduced turbidity levels were also a strong contributor to $A C K-M 1$ relative abundance.

The shifts in BCC observed here were driven by fluctuating physical and chemical conditions associated with an inflow event and are to some extent indicative of substrate-controlled succession of microbial communities within this ecosystem. While successional patterns among bacterial communities associated with algal blooms and nutrient upwellings have been widely reported in marine and lake environments (Kritzberg et al. 2004, Rösel \& Grossart 2012, Teeling et al. 2012), investigations of large freshwater inflow events that describe successional changes in bacterial communities in lotic systems, particularly of the magnitude we observed in the Hunter River, are rarer. However, extrinsic, climaterelated factors have previously been identified as the best predictors of seasonal microbial community patterns, whereby in a 3 year temporal study of 2 independent temperate rivers temperature and flow rates were found to be key drivers of bacterial diversity (Crump \& Hobbie 2005). However, the rapid, shortterm physical changes caused by large-scale floods likely override these seasonal patterns (Junk et al. 1989, Tockner et al. 2000) and lead to temporary restructuring of bacterial communities. A possible driver of rapid compositional shifts is the input of allochthonous substrate into rivers during flood events, which subsequently lead to rapid successional changes in microbial assemblages (Mašín et al. 2003, Chung et al. 2014, Santos et al. 2014).

Substrate-controlled succession occurs in bacterioplankton communities when new pulses of resources become available and are subsequently depleted by different members of the microbial assemblages. Following pulse inputs of chemical resources, specialist copiotrophic microbes that may normally persist at low abundances rapidly exploit substrate pulses and increase in abundance (Lauro et al. 2009, Patel et al. 2014). The subsequent production of secondary metabolites and mineralised nutrients can then fuel the rise of other groups of microbes. Alternatively, as the original resource pulse is exhausted or physicochemical conditions change the microbial community shifts further. We propose that major river inflow events provide allochthonous fuel which catalyses successional processes within river ecosystems.

Taking our data into consideration, we suggest that a typical lotic microbial response to a major inflow or flood event would be as follows: The massive introduction of allochthonous DOC and inorganic nutrients during a flood event is followed by an increase in the activity and abundance of heterotrophic bacterial populations as has been reported in several previous investigations of bacterial productivity in coastal aquatic environments (Pinhassi et al. 2006, Hitchcock et al. 2010, Pollard \& Ducklow 2011). The concomitant increase in turbidity levels during the flood will restrict photoautotrophic activity, leading to a reduction in cyanobacterial and phytoplankton biomass (Henley et al. 2000). This shift in community metabolism towards heterotrophy will support the establishment of anoxic conditions and the subsequent increase in anaerobic bacterial communities (Walsh et al. 2004, Diaz \& Rosenberg 2008, Zhang et al. 2010). In addition, the flood event will likely lead to the transport of non-endemic bacterial groups and anaerobic bacteria including sulphate-reducing bacteria (Miletto et al. 2008) from surrounding terrestrial sources within the catchment, into the river environment (Edwards \& Meyer 1986, Crump \& Hobbie 2005). Following the flood event, during the river's recovery phase, the exhaustion of allochthonous DOC and the gradual reduction in turbidity levels will allow for the re-establishment of photoautotrophic microbes, which will likely also benefit from the pool of remineralised nutrients resulting from the heterotrophic bloom during the flood. These results reveal the importance of river inflow events and floods as a significant driver of physico-chemical conditions which subsequently influence spatiotemporal patterns in the composition of bacterial communities, ultimately shaping the ecology of river ecosystems.

\section{CONCLUSIONS}

Inflow events are likely a fundamental driver of microbial community dynamics within river ecosystems, but to date have been largely neglected. The results of this study illustrate that high inflows and 
black water events can lead to profound changes in water chemistry and nutrient profiles, which stimulate sharp increases in bacterial cell abundance and phylogenetic shifts in BCC. The changes in BCC observed here are indicative of a substrate-controlled succession process, providing evidence that medium to large freshwater inflow events are an important driver of spatiotemporal heterogeneity in the bacterial communities of rivers. This research provides fundamental insights needed to understand how transportation of allochthonous nutrients via inflow events influence the bacterial communities at the base of riverine food webs, and what implications this may have for lotic ecological health.

Acknowledgements. We acknowledge the contributions of the New South Wales Office of Water and thank them for providing nutrient data and the use of their boat for sample collection. This project was funded by the University of Technology, Sydney - School of Environment (SoE), and the Plant Functionality and Climate Change Cluster (C3). This project was funded by the Australian Research Council Grants DP120102764 and FT130100218 to J.R.S.

\section{LITERATURE CITED}

Acinas SG, Antón J, Rodríguez-Valera F (1999) Diversity of free-living and attached bacteria in offshore western Mediterranean waters as depicted by analysis of genes encoding 16S rRNA. Appl Environ Microbiol 65:514-522

Almeida MA, Cunha MA, Alcantara F (2005) Relationship of bacterioplankton production with primary production and respiration in a shallow estuarine system (Ria de Aveiro, NW Portugal). Microbiol Res 160:315-328

Altschul SF, Gish W, Miller W, Myers EW, Lipman DJ (1990) Basic local alignment search tool. J Mol Biol 215:403-410

Ameryk A, Podgórska B, Witek Z (2005) The dependence between bacterial production and environmental conditions in the Gulf of Gdańsk. Oceanologia 47:27-45

Anderson MJ (2001) A new method for non parametric multivariate analysis of variance. Austral Ecol 26:32-46

Anderson M, Gorley R, Clarke K (2007) PERMANOVA+ for PRIMER: a guide to software and statistical methods. Primer-e, Plymouth

- Arthington AH, Pusey BJ (2003) Flow restoration and protection in Australian rivers. River Res Appl 19:377-395

Arthington AH, Bunn SE, Poff NL, Naiman RJ (2006) The challenge of providing environmental flow rules to sustain river ecosystems. Ecol Appl 16:1311-1318

> Azam F, Hodson R (1977) Size distribution and activity of marine microheterotrophs. Limnol Oceanogr 22:492-501

Azam F, Fenchel T, Field J, Gray J, Meyer-Reil L, Thingstad $F$ (1983) The ecological role of water-column microbes in the sea. Mar Ecol Prog Ser 10:257-263

Baldwin D, Wilson J, Gigney H, Boulding A (2010) Influence of extreme drawdown on water quality downstream of a large water storage reservoir. River Res Appl 26:194-206

Blum LK, Mills AL (2012) Estuarine microbial ecology. In: Day JW, Crump BC, Kemp WM, Yáñez-Arancibia A (eds) Estuarine ecology, 2nd edn. Wiley-Blackwell, p 235-261
Brown MV, Schwalbach MS, Hewson I, Fuhrman JA (2005) Coupling 16S ITS rDNA clone libraries and automated ribosomal intergenic spacer analysis to show marine microbial diversity: development and application to a time series. Environ Microbiol 7:1466-1479

Caporaso JG, Kuczynski J, Stombaugh J, Bittinger K and others (2010) QIIME allows analysis of high-throughput community sequencing data. Nat Methods 7:335-336

> Carvalho P, Thomaz S, Bini L (2003) Effects of water level, abiotic and biotic factors on bacterioplankton abundance in lagoons of a tropical floodplain (Paraná River, Brazil). Hydrobiologia 510:67-74

Chung CC, Huang CY, Gong GC, Lin YC (2014) Influence of the Changjiang River flood on Synechococcus ecology in the surface waters of the East China Sea. Microb Ecol 67: 273-285

> Cole JJ, Caraco NF (2001) Carbon in catchments: connecting terrestrial carbon losses with aquatic metabolism. Mar Freshw Res 52:101-110

Crespo BG, Pommier T, Fernández Gómez B, Pedrós Alió C (2013) Taxonomic composition of the particle-attached and free-living bacterial assemblages in the Northwest Mediterranean Sea analyzed by pyrosequencing of the 16S rRNA. MicrobiologyOpen 2:541-552

Crump BC, Hobbie JE (2005) Synchrony and seasonality in bacterioplankton communities of two temperate rivers. Limnol Oceanogr 50:1718-1729

> Crump BC, Hopkinson CS, Sogin ML, Hobbie JE (2004) Microbial biogeography along an estuarine salinity gradient: combined influences of bacterial growth and residence time. Appl Environ Microbiol 70:1494-1505

> Curtis TP, Sloan WT (2004) Prokaryotic diversity and its limits: microbial community structure in nature and implications for microbial ecology. Curr Opin Microbiol 7: 221-226

Dalzell BJ, Filley TR, Harbor JM (2007) The role of hydrology in annual organic carbon loads and terrestrial organic matter export from a midwestern agricultural watershed. Geochim Cosmochim Acta 71:1448-1462

Del Giorgio PA, Cole JJ (1998) Bacterial growth efficiency in natural aquatic systems. Annu Rev Ecol Syst 29:503-541

Del Giorgio PA, Williams PJleB (2005) Respiration in aquatic ecosystems. Oxford University Press, Oxford

Dennis PG, Seymour J, Kumbun K, Tyson GW (2013) Diverse populations of lake water bacteria exhibit chemotaxis towards inorganic nutrients. ISME $\mathrm{J}$ 7: 1661-1664

> DeSantis TZ, Hugenholtz P, Larsen N, Rojas M and others (2006) Greengenes, a chimera-checked 16S rRNA gene database and workbench compatible with ARB. Appl Environ Microbiol 72:5069-5072

Diaz RJ, Rosenberg R (2008) Spreading dead zones and consequences for marine ecosystems. Science 321:926-929

Dudgeon D (2010) Prospects for sustaining freshwater biodiversity in the 21st century: linking ecosystem structure and function. Curr Opin Environ Sustain 2:422-430

Dudgeon D, Arthington AH, Gessner MO, Kawabata ZI and others (2006) Freshwater biodiversity: importance, threats, status and conservation challenges. Biol Rev Camb Philos Soc 81:163-182

Eaton AD, Franson MAH (2005) Standard methods for the examination of water \& wastewater, 21st edn. American Public Health Association, Washington, DC

Eaton AD, Clesceri LS, Greenberg AE, Franson MAH (1995) Standard methods for the examination of water and 
wastewater, 19th edn. American Public Health Association, Washington, DC

- Edgar RC, Haas BJ, Clemente JC, Quince C, Knight R (2011) UCHIME improves sensitivity and speed of chimera detection. Bioinformatics 27:2194-2200

Edwards RT, Meyer JL (1986) Production and turnover of planktonic bacteria in two southeastern blackwater rivers. Appl Environ Microbiol 52:1317-1323

Entwisle TJ, Sonneman JA, Lewis SH (1997) Freshwater algae in Australia. Sainty \& Associates, Sydney

Farjalla VF, Marinho CC, Faria BM, Amado AM, Esteves FdeA, Bozelli RL, Giroldo D (2009) Synergy of fresh and accumulated organic matter to bacterial growth. Microb Ecol 57:657-666

Fawcett SE, Ward BB (2011) Phytoplankton succession and nitrogen utilization during the development of an upwelling bloom. Mar Ecol Prog Ser 428:13-31

> Fuhrman JA, Steele JA (2008) Community structure of marine bacterioplankton: patterns, networks, and relationships to function. Aquat Microb Ecol 53:69-81

García-Armisen T, İnceoğlu Ö, Ouattara NK, Anzil A, Verbanck MA, Brion N, Servais P (2014) Seasonal variations and resilience of bacterial communities in a sewage polluted urban river. PLoS ONE 9:e92579

Gasol JM, Del Giorgio PA (2000) Using flow cytometry for counting natural planktonic bacteria and understanding the structure of planktonic bacterial communities. Sci Mar 64:197-224

Gibbons SM, Caporaso JG, Pirrung M, Field D, Knight R, Gilbert JA (2013) Evidence for a persistent microbial seed bank throughout the global ocean. Proc Natl Acad Sci USA 110:4651-4655

> Gram L, Melchiorsen J, Bruhn JB (2010) Antibacterial activity of marine culturable bacteria collected from a global sampling of ocean surface waters and surface swabs of marine organisms. Mar Biotechnol 12:439-451

> Haas BJ, Gevers D, Earl AM, Feldgarden M and others (2011) Chimeric 16S rRNA sequence formation and detection in Sanger and 454-pyrosequenced PCR amplicons. Genome Res 21:494-504

> Hadwen WL, Fellows CS, Westhorpe DP, Rees GN and others (2010) Longitudinal trends in river functioning: patterns of nutrient and carbon processing in three Australian rivers. River Res Appl 26:1129-1152

> Hahn MW, Kasalický V, Jezbera J, Brandt U, Jezberová J, Šimek K (2010) Limnohabitans curvus gen. nov., sp. nov., a planktonic bacterium isolated from a freshwater lake. Int J Syst Evol Microbiol 60:1358-1365

Halstvedt CB, Rohrlack T, Andersen T, Skulberg O, Edvardsen B (2007) Seasonal dynamics and depth distribution of Planktothrix spp. in Lake Steinsfjorden (Norway) related to environmental factors. J Plankton Res 29:471-482

Havens KE, Work KA, East TL (2000) Relative efficiencies of carbon transfer from bacteria and algae to zooplankton in a subtropical lake. J Plankton Res 22:1801-1809

Henley W, Patterson M, Neves R, Lemly AD (2000) Effects of sedimentation and turbidity on lotic food webs: a concise review for natural resource managers. Rev Fish Sci 8: 125-139

Hewson I, Fuhrman JA (2004) Richness and diversity of bacterioplankton species along an estuarine gradient in Moreton Bay, Australia. Appl Environ Microbiol 70: 3425-3433

> Hitchcock JN, Mitrovic SM (2013) Different resource limitation by carbon, nitrogen and phosphorus between base flow and high flow conditions for estuarine bacteria and phytoplankton. Estuar Coast Shelf Sci 135:106-115

Hitchcock JN, Mitrovic SM (2014) Highs and lows: the effect of differently sized freshwater inflows on estuarine carbon, nitrogen, phosphorus, bacteria and chlorophyll a dynamics. Estuar Coast Shelf Sci 156:71-82

Hitchcock JN, Mitrovic SM, Kobayashi T, Westhorpe DP (2010) Responses of estuarine bacterioplankton, phytoplankton and zooplankton to dissolved organic carbon (DOC) and inorganic nutrient additions. Estuaries Coasts 33:78-91

Jansson M, Bergström AK, Lymer D, Vrede K, Karlsson J (2006) Bacterioplankton growth and nutrient use efficiencies under variable organic carbon and inorganic phosphorus ratios. Microb Ecol 52:358-364

Junk WJ, Bayley PB, Sparks RE (1989) The flood pulse concept in river-floodplain systems. Publ Spec Can Sci Halieut Aquat 106:110-127

Kelly DP, Wood AP, Stackebrandt E (2005) Genus II Thiobacillus Beijerinck 1904 ${ }^{\mathrm{b}}, 597^{\mathrm{AL}}$. In: Brenner DJ, Krieg NR, Staley JT, Garrity GM (eds) Bergey's Manual® of Systematic Bacteriology, 2nd edn, Vol 2, Part C. Springer, New York, NY, p 764-769

Kim M, Morrison M, Yu Z (2011) Evaluation of different partial 16S rRNA gene sequence regions for phylogenetic analysis of microbiomes. J Microbiol Methods 84:81-87

Kirchman DL, Dittel AI, Findlay SE, Fischer D (2004) Changes in bacterial activity and community structure in response to dissolved organic matter in the Hudson River, New York. Aquat Microb Ecol 35:243-257

Kritzberg E, Cole JJ, Pace ML, Granéli W, Bade DL (2004) Autochthonous versus allochthonous carbon sources of bacteria: results from whole-lake C-13 addition experiments. Limnol Oceanogr 49:588-596

Kumar PS, Brooker MR, Dowd SE, Camerlengo T (2011) Target region selection is a critical determinant of community fingerprints generated by $16 \mathrm{~S}$ pyrosequencing. PLoS ONE 6:e20956

Lauro FM, McDougald D, Thomas T, Williams TJ and others (2009) The genomic basis of trophic strategy in marine bacteria. Proc Natl Acad Sci USA 106:15527-15533

Liao PC, Huang BH, Huang S (2007) Microbial community composition of the Danshui river estuary of Northern Taiwan and the practicality of the phylogenetic method in microbial barcoding. Microb Ecol 54:497-507

Lin X, McKinley J, Resch CT, Kaluzny R and others (2012) Spatial and temporal dynamics of the microbial community in the Hanford unconfined aquifer. ISME $\mathrm{J} 6$ : 1665-1676

Maranger RJ, Pace ML, del Giorgio PA, Caraco NF, Cole JJ (2005) Longitudinal spatial patterns of bacterial production and respiration in a large river-estuary: implications for ecosystem carbon consumption. Ecosystems 8:318-330

Marie D, Partensky F, Jacquet S, Vaulot D (1997) Enumeration and cell cycle analysis of natural populations of marine picoplankton by flow cytometry using the nucleic acid stain SYBR Green I. Appl Environ Microbiol 63: 186-193

Mašín M, Jezbera J, Nedoma J, Straškrabová V, Hejzlar J, Šimek K (2003) Changes in bacterial community composition and microbial activities along the longitudinal axis of two canyon-shaped reservoirs with different inflow loading. Hydrobiologia 504:99-113

McDonald D, Price MN, Goodrich J, Nawrocki EP and others (2011) An improved Greengenes taxonomy with 
explicit ranks for ecological and evolutionary analyses of bacteria and archaea. ISME J 6:610-618

Miletto M, Loy A, Antheunisse AM, Loeb R, Bodelier PL, Laanbroek HJ (2008) Biogeography of sulfate-reducing prokaryotes in river floodplains. FEMS Microbiol Ecol 64:395-406

Mitrovic SW, Westhorpe DP, Kobayashi T, Baldwin DS, Ryan D, Hitchcock JN (2014) Short-term changes in zooplankton density and community structure in response to different sources of dissolved organic carbon in an unconstrained lowland river: evidence for food web support. J Plankton Res 36:1488-1500

Nair S, Simidu U (1987) Distribution and significance of heterotrophic marine bacteria with antibacterial activity. Appl Environ Microbiol 53:2957-2962

Newton RJ, Jones SE, Eiler A, McMahon KD, Bertilsson S (2011) A guide to the natural history of freshwater lake bacteria. Microbiol Mol Biol Rev 75:14-49

NSWDPI (2003) The Hunter regulated river water sharing plan. New South Wales Department of Primary Industries, Orange

Paerl HW, Pinckney JL, Fear JM, Peierls BL (1998) Ecosystem responses to internal and watershed organic matter loading: consequences for hypoxia in the eutrophying Neuse River Estuary, North Carolina, USA. Mar Ecol Prog Ser 166:17-25

Palijan G, Bogut I, Vidakovic J (2008) The impact of inundation-isolation cycles on the culturable bacterioplankton in the Danube River floodplain. Pol J Ecol 56:391-403

Partensky F, Blanchot J, Vaulot D (1999) Differential distribution and ecology of Prochlorococcus and Synechococcus in oceanic waters: a review. Bull Inst Ocean Monaco Spec Issue 19:457-476

Patel V, Munot H, Shouche YS, Madamwar D (2014) Response of bacterial community structure to seasonal fluctuation and anthropogenic pollution on coastal water of Alang-Sosiya ship breaking yard, Bhavnagar, India. Bioresour Technol 161:362-370

Petrone KC, Richards JS, Grierson PF (2009) Bioavailability and composition of dissolved organic carbon and nitrogen in a near coastal catchment of south-western Australia. Biogeochemistry 92:27-40

Pinhassi J, Gómez-Consarnau L, Alonso-Sáez L, Sala MM, Vidal M, Pedrós-Alió C, Gasol JM (2006) Seasonal changes in bacterioplankton nutrient limitation and their effects on bacterial community composition in the NW Mediterranean Sea. Aquat Microb Ecol 44:241-252

> Poff NL, Zimmerman JK (2010) Ecological responses to altered flow regimes: a literature review to inform the science and management of environmental flows. Freshw Biol 55:194-205

Pollard PC, Ducklow HW (2011) Ultrahigh bacterial production in a eutrophic subtropical Australian river: does viral lysis short-circuit the microbial loop? Limnol Oceanogr 56:1115-1129

Pujalte MJ, Lucena T, Ruvira MA, Arahal DR, Macián MC (2014) The family Rhodobacteraceae, Vol 1. Springer, Berlin

Ramette A (2009) Quantitative community fingerprinting methods for estimating the abundance of operational taxonomic units in natural microbial communities. Appl Environ Microbiol 75:2495-2505

Reshef D, Reshef Y, Finucane H, Grossman S and others (2011) Detecting novel associations in large datasets. Science 334:1518-1524
Riemann L, Winding A (2001) Community dynamics of freeliving and particle-associated bacterial assemblages during a freshwater phytoplankton bloom. Microb Ecol 42: 274-285

Rösel S, Grossart HP (2012) Contrasting dynamics in activity and community composition of free-living and particleassociated bacteria in spring. Aquat Microb Ecol 66: 169-181

Rossi P, Shani N, Kohler F, Imfeld G, Holliger C (2012) Ecology and biogeography of bacterial communities associated with chloroethene-contaminated aquifers. Front Microbiol 3:260

Salles P, Bredeweg B, Araújo S (2006) Qualitative models about stream ecosystem recovery: exploratory studies. Ecol Modell 194:80-89

Santos L, Vaz L, Marcial Gomes NC, Vaz N, Dias JM, Cunha $\hat{A}$, Almeida A (2014) Impact of freshwater inflow on bacterial abundance and activity in the estuarine system Ria de Aveiro. Estuar Coast Shelf Sci 138:107-120

Schultz GE Jr, Kovatch JJ, Anneken EM (2013) Bacterial diversity in a large, temperate, heavily modified river, as determined by pyrosequencing. Aquat Microb Ecol 70: 169-179

Seymour JR, Patten N, Bourne DG, Mitchell JG (2005) Spatial dynamics of virus-like particles and heterotrophic bacteria within a shallow coral reef system. Mar Ecol Prog Ser 288:1-8

Sieczko A, Peduzzi P (2014) Origin, enzymatic response and fate of dissolved organic matter during flood and nonflood conditions in a river-floodplain system of the Danube (Austria). Aquat Sci 76:115-129

Sinsabaugh RL, Findlay SEG (2003) Dissolved organic matter: out of the black box into the mainstream. In: Findlay SEG, Sinsabaugh RL (eds) Aquatic ecosystems: interactivity of dissolved organic matter. Elsevier, San Diego, CA, p 479-498

Stahl DA, Hullar M, Davidson S (2006) The structure and function of microbial communities. In: Dworkin M, Falkow S, Rosenberg E, Schleifer KH, Stackebrandt E (eds) The prokaryotes. Springer, New York, NY, p 299-327

> Steele JA, Countway PD, Xia L, Vigil PD and others (2011) Marine bacterial, archaeal and protistan association networks reveal ecological linkages. ISME J 5:1414-1425

> Tang KW, Dziallas C, Grossart HP (2011) Zooplankton and aggregates as refuge for aquatic bacteria: protection from UV, heat and ozone stresses used for water treatment. Environ Microbiol 13:378-390

Tang X, Gao G, Qin B, Zhu L, Chao J, Wang J, Yang G (2009) Characterization of bacterial communities associated with organic aggregates in a large, shallow, eutrophic freshwater lake (Lake Taihu, China). Microb Ecol 58:307-322

Teeling H, Fuchs BM, Becher D, Klockow C and others (2012) Substrate-controlled succession of marine bacterioplankton populations induced by a phytoplankton bloom. Science 336:608-611

> Thiele S, Fuchs BM, Amann R, Iversen MH (2014) Colonization in the photic zone and subsequent changes during sinking determine bacterial community composition in marine snow. Appl Environ Microbiol 81:1463-1471

Tockner K, Malard F, Ward J (2000) An extension of the flood pulse concept. Hydrol Process 14:2861-2883

- Van der Gucht K, Vandekerckhove T, Vloemans N, Cousin S and others (2005) Characterization of bacterial communi- 
ties in four freshwater lakes differing in nutrient load and food web structure. FEMS Microbiol Ecol 53:205-220

Vörösmarty CJ, McIntyre P, Gessner MO, Dudgeon D and others (2010) Global threats to human water security and river biodiversity. Nature 467:555-561

Walsh S, Copeland C, Westlake M (2004) Major fish kills in the northern rivers of NSW in 2001: causes, impacts and responses. Fisheries final report series no. 68. New South Wales Department of Primary Industries, Orange

> Wear EK, Koepfler ET, Smith EM (2013) Spatiotemporal variability in dissolved organic matter composition is more strongly related to bacterioplankton community composition than to metabolic capability in a blackwater estuarine system. Estuaries Coasts 37:119-133

Webster IT, Harris GP (2004) Anthropogenic impacts on the ecosystems of coastal lagoons: modelling fundamental biogeochemical processes and management implications. Mar Freshw Res 55:67-78

Westhorpe DP, Mitrovic SM (2012) Dissolved organic carbon mobilisation in relation to variable discharges and environmental flows in a highly regulated lowland river. Mar Freshw Res 63:1218-1230

Westhorpe DP, Mitrovic SM, Ryan D, Kobayashi T (2010) Limitation of lowland riverine bacterioplankton by dissolved organic carbon and inorganic nutrients. Hydrobiologia 652:101-117

Wilson JG, Devlin M (2013) Nutrients, food web and trophodynamic processes. Estuar Coast Shelf Sci 135:1-4

Zhang J, Gilbert D, Gooday A, Levin L and others (2010) Natural and human-induced hypoxia and consequences for coastal areas: synthesis and future development. Biogeosciences 7:1443-1467

Zhou J, Deng Y, Luo F, He Z, Tu Q, Zhi X (2010) Functional molecular ecological networks. MBio 1:e00169-10

Zwart G, Crump BC, Kamst-van Agterveld MP, Hagen F, Han SK (2002) Typical freshwater bacteria: an analysis of available 16S rRNA gene sequences from plankton of lakes and rivers. Aquat Microb Ecol 28:141-155

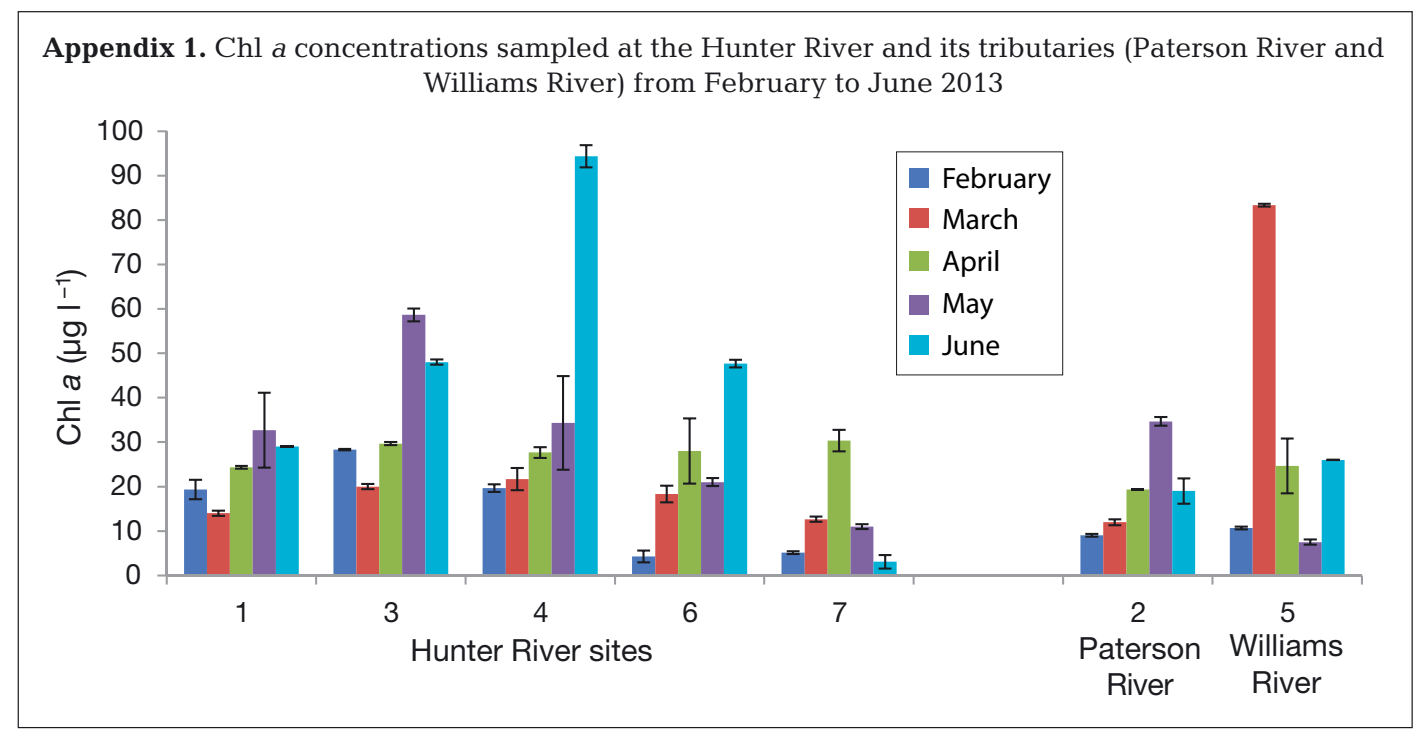

Editorial responsibility: Tom Battin, Vienna, Austria
Submitted: August 4, 2014; Accepted: April 22, 2015

Proofs received from author(s): June 24, 2015 